\title{
Culinary-medicinal mushrooms: a review of organic compounds and bioelements with antioxidant activity
}

\author{
Adrian Podkowa ${ }^{1} \cdot$ Agata Kryczyk-Poprawa $^{1} \cdot$ Włodzimierz Opoka ${ }^{1} \cdot$ Bożena Muszyńska² $₫$
}

Received: 21 August 2020 / Revised: 26 October 2020 / Accepted: 31 October 2020 / Published online: 27 November 2020

(c) The Author(s) 2020

\begin{abstract}
There are about 3000 species of mushrooms, which have a high amount of substances that are beneficial to human health, such as antioxidants. It is well known that oxidative stress plays an important role in the etiopathogenesis of many diseases, including cancer, cardiovascular disorders, and diseases of the central nervous system. One way to prevent homeostasis disorders that occur as a result of excessive production of pro-oxidative substances is to include the ingredients having antioxidant properties in the diet. Several compounds, such as those with phenolic and indole derivatives as well as carotenoids and some vitamins, exhibit antioxidant activity. These substances are present in many foods, including mushrooms. In addition, they have certain unique compounds that are not found in other sources (e.g., norbadione A). The present work discusses selected ingredients exhibiting antioxidant activity, which are found in various species of mushrooms as wells as describes the content of these compounds in the extracts obtained from mushrooms using artificial digestive juice.
\end{abstract}

Keywords Antioxidant activity $\cdot$ Culinary $\cdot$ Medicinal mushrooms $\cdot$ Gastric juices $\cdot$ Oxidative stress

\section{Introduction}

Oxidative stress occurs when the defense mechanisms of the body fail to neutralize the effects of reactive oxygen species (ROS) or other factors possessing strong oxidative activity, such as reactive nitrogen species (RNS). These substances are capable of exerting damaging effects on cells. ROS include, among others, superoxide anion $\left(\mathrm{O}_{2}{ }^{\bullet-}\right)$, hydroxyl radical $\left({ }^{\bullet} \mathrm{OH}\right)$, hydrogen peroxide $\left(\mathrm{H}_{2} \mathrm{O}_{2}\right)$, and singlet oxygen $\left({ }^{1} \mathrm{O}_{2}\right)$, while RNS include nitric oxide (NO) and peroxynitrite $\left(\mathrm{ONOO}^{-}\right)[1,2]$. Both RNS and ROS are constantly produced in a living body: they arise, among others, as a by-product of cellular respiration, as well as in the course of immunological reactions. When secreted by the cells of the immune system, ROS and RNS play a significant role participating in the defense mechanisms of the body against

Bożena Muszyńska

muchon@poczta.fm

1 Faculty of Pharmacy, Department of Inorganic and Analytical Chemistry, Jagiellonian University Medical College, 9 Medyczna Street, 30-688 Kraków, Poland

2 Faculty of Pharmacy, Department of Pharmaceutical Botany, Jagiellonian University Medical College, 9 Medyczna Street, 30-688 Kraków, Poland pathogens. In the physiological conditions, a number of endogenous compounds displaying antioxidant activity contribute to neutralizing the effects of reactive oxygen and nitrogen. These compounds include certain enzymes (e.g., superoxide dismutase, catalase, and glutathione peroxidase), vitamins (e.g., C and E), flavonoids, phenolic compounds, and glutathione which is considered as the strongest antioxidant [3]. The abovementioned enzymes prevent the development of oxidative stress by neutralizing the oxidizing substances as follows: superoxide dismutase - this group of enzymes convert a superoxide anion radical into hydrogen peroxide and are also found associated with various metals such as zinc, copper, iron, and manganese [4]; catalaseparticipates in the decomposition of hydrogen peroxide into oxygen and water [5]; and glutathione peroxidaseinvolved in the neutralization of peroxides (both hydrogen and organic peroxides) [6].

Oxidative stress plays an important role in the etiology and course of numerous diseases such as diabetes, atherosclerosis, Alzheimer's disease, Parkinson's disease, chronic kidney disease, and chronic obstructive pulmonary disease [7-10]. One way to prevent these disorders related to oxidative damage is to take a diet rich in natural antioxidants. Mushrooms are identified as an excellent source of antioxidant substances, such as phenolic compounds, indole 
compounds, and carotenoids. They are also rich in vitamins and minerals possessing antioxidant properties [11-13].

At the stage of the existing destruction of the natural environment, including the use of animal husbandry, the most important current trend is the search for healthy and prophylactically effective food, especially one that can replace products of animal origin. Another problem is excessive production of free radicals into the environment. One part of the nutritional response could be mushroom species, classified also as medicinal. Therefore, the aim of the present work is to highlight the most important organic compounds and bioelements exhibiting antioxidant activity that are found in various species of culinary-medicinal mushrooms.

\section{Organic compounds}

\section{Phenolic compounds}

Phenolic compounds are a heterogeneous group of plant and fungal metabolites [14]. Some of the phenolic acids present in mushroom species are chlorogenic, gallic, caffeic, protocatechuic, and syringic acid (Fig. 1) [15]. Phenolic substances also include a group of compounds called flavonoids. It has been documented that the strong antioxidant activity of the phenolic compounds is imparted by a large number of hydroxyl groups [16].

Mushrooms are a rich source of phenolic compounds [17, 18]. A high content of these substances has been identified in species growing in Europe and in other parts of the world. Yildiz et al. [18] determined the content of phenolic derivatives in the following four species of mushrooms: Ganoderma lucidum, Morchella esculenta, Lentinula edodes, and Hericium erinaceus. The concentration of phenolic
Fig. 1 Chemical structures of chlorogenic acid (a), gallic acid (b), caffeic acid (c), protocatechuic acid (d), and syringic acid (s)
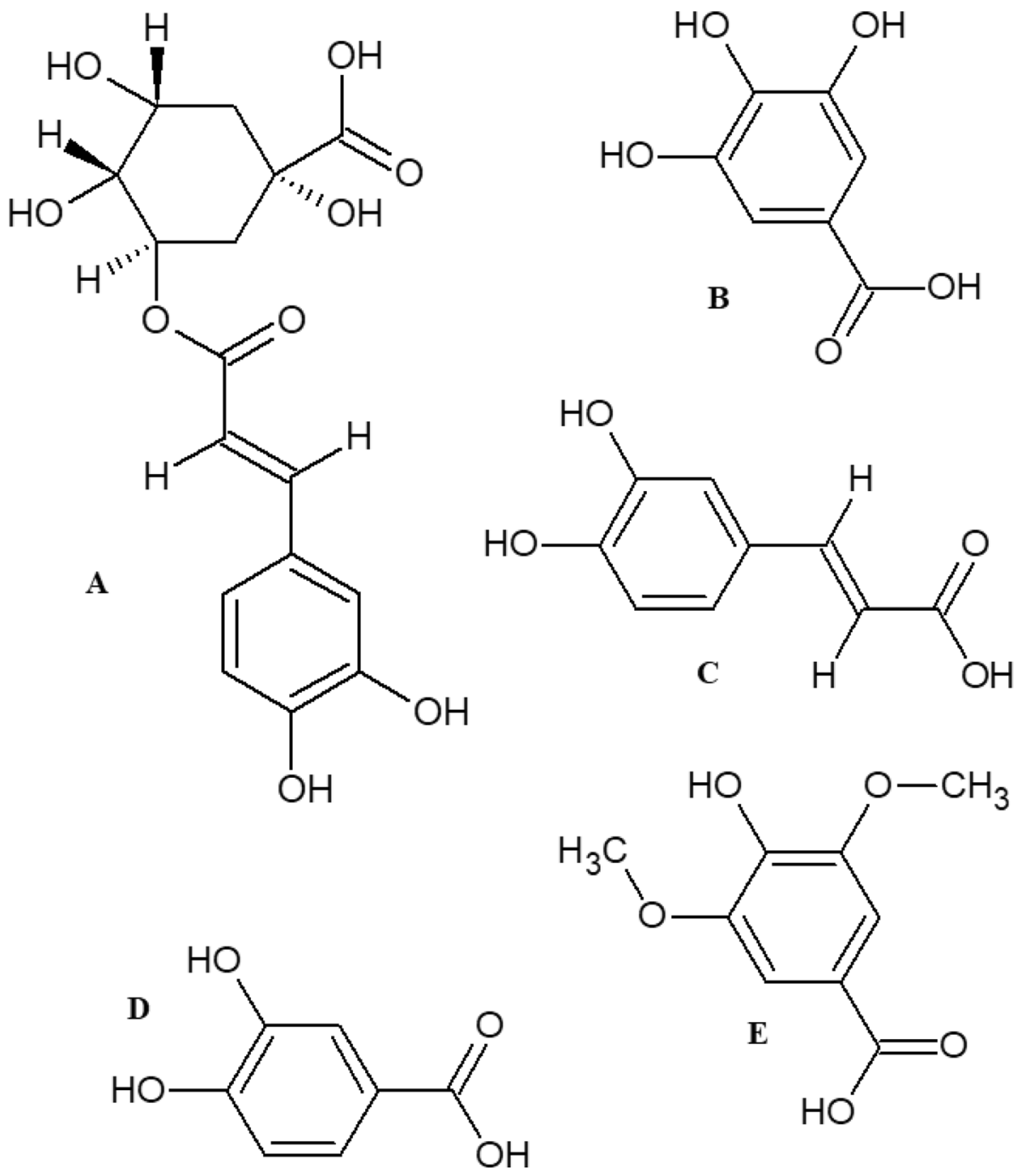
compounds, calculated as the amount of gallic acid, was found to be the highest in G. lucidum-over $26.00 \mathrm{mg} / \mathrm{g}$ dry weight (d.w.). A comparable amount was found in $M$. esculenta ( $25.00 \mathrm{mg} / \mathrm{g}$ d.w.); while in L. edodes and H. erinaceus, the content did not exceed $10.00 \mathrm{mg} / \mathrm{g}$ d.w. and was estimated as 7.25 and $5.81 \mathrm{mg} / \mathrm{g}$ d.w., respectively [18].

Muszyńska et al. [19] compared the amount of phenolic derivatives in the following mushroom species: Armillaria mellea, Imleria badia (= Boletus badius), Boletus edulis, Cantharellus cibarius, Lactarius deliciosus, and Pleurotus ostreatus. The authors identified the highest total amount of the phenolic derivatives in I. badia $(48.25 \mathrm{mg} / \mathrm{kg}$ d.w.); while in the remaining species, the amount was in the range between 6.00 and $19.72 \mathrm{mg} / \mathrm{kg}$ d.w.

Butkhup et al. [17] tested as many as 25 species of mushrooms from Thailand for the content of phenolic compounds in their study. The highest concentration was found in Termitomyces clypeatus, in which the amount of gallic acid was $8.84 \mathrm{mg} / \mathrm{g}$ d.w. A very similar amount was determined in Amanita hemibapha and Volvariella volvacea with 8.53 and $8.49 \mathrm{mg} / \mathrm{g}$ d.w., respectively [17].

Gąsecka et al. [20] examined the content of phenolic compounds in P. ostreatus and Pleurotus eryngii grown in media with and without zinc and selenium. In the cultures without the addition of these minerals, only mediocre amounts of phenolic compounds were found (expressed in $\mathrm{mg} / \mathrm{g}$ d.w. as the equivalent of chlorogenic acid; approximately $9.60 \mathrm{mg} / \mathrm{g}$ d.w. in P. ostreatus and $7.90 \mathrm{mg} / \mathrm{g}$ d.w. in P. eryngii). By contrast, the cultures enriched with zinc and selenium had a higher content of phenolic derivatives (about 13.40 and $10.90 \mathrm{mg} / \mathrm{g} \mathrm{d}$.w., respectively). The following phenolic acids were found in both species of the mushrooms studied: 4-hydroxybenzoic, ferulic, $p$-coumaric, protocatechuic, trans-cinnamic, and vanillic acid (2,5-dihydroxybenzoic acid was detected only in P. eryngii) [20].

Alispahić et al. [21] analyzed the composition of the extracts isolated from mushrooms such as B. edulis, $L$. edodes, and $P$. ostreatus, which were obtained from the Bosnian market, to identify the phenolic compounds with antioxidant activity present in them. The highest content of phenolic compounds, calculated as gallic acid, was found in B. edulis (over $35.00 \mathrm{mg} / \mathrm{g} \mathrm{d.w}$ ); while, the level of the phenolic substances in the other two species was lower (approximately $6.30 \mathrm{mg} / \mathrm{g}$ d.w. in P. ostreatus and $4.90 \mathrm{mg} / \mathrm{g}$ d.w. in L. edodes) [21].

Agaricus genus contains many popular species which are rich in phenolic compounds. Gąsecka et al. [22] examined the content of phenolic derivatives in various species of Agaricus including Agaricus bisporus, Agaricus blazei, Agaricus arvensis, Agaricus bitorquis, Agaricus campestris, and Agaricus silvaticus. The highest amount of phenolic compounds, calculated as gallic acid, was determined in A. blazei (over $11.50 \mathrm{mg} / \mathrm{g} \mathrm{d} . \mathrm{w}$.); while, the white varieties of A. bisporus mushrooms were characterized by a much lower content of phenolic substances (ranging from 1.30 to $6.20 \mathrm{mg} / \mathrm{g} \mathrm{d.w.)} \mathrm{[22].} \mathrm{The} \mathrm{antioxidant} \mathrm{activity} \mathrm{assessed} \mathrm{by}$ the DPPH (1,1-diphenyl-2-picrylhydrazyl) radical scavenging test was directly proportional to the content of phenolic compounds. The authors identified several phenolic acids in the fruiting bodies of the Agaricus mushrooms, of which gallic, caffeic, $p$-hydroxybenzoic, $p$-coumaric, and ferulic acid were specially mentioned [22]. They exhibit a wide spectrum of biological activities which have been attributed to their strong antioxidant activity and ability to protect vital cellular structures, like cell membranes, and also structural proteins, enzymes, membrane lipids or nucleic acids [23]. The strongest antioxidant properties and capability of cell protection against hydrogen peroxide were evidenced for vanillic acid, cinnamic acid derivatives, caffeic acid.

$p$-Hydroxybenzoic, gallic and protocatechuic acids found in mushrooms are characterized by antioxidant, antibacterial, antiviral, antifungal, anti-inflammatory and gastric secretion-stimulatory actions, documented by in vitro and in vivo studies [24]. In addition, protocatechuic acid was shown to possess immunomodulating, spasmolytic, cardioprotectant, anticoagulant and chemopreventive properties. Phenolic acids from Inonotus hispidus were proved to be protective against influenza virus types A and B [25]. A strong positive correlation was observed between antioxidant activity of mushrooms and the amount of phenolic compounds [26].

Muszyńska et al. determined the examples of the phenolic compounds and other antioxidant substances present in selected mushroom species are showed and compared in Table 1.

\section{Norbadione A}

Belonging to the class of phenolic compounds, norbadione A (Fig. 2) is a dark brown dye found, among others, in the hats of I. badia and is proved to have antioxidant properties [27]. The protective effect of this compound against harmful ionizing radiation was also investigated [28] in a study using cell cultures and mice. The results of the study showed that norbadione A increased the strength of TK6 lymphoid cells and prolonged the survival of irradiated mice. However, the compound was found to exert cell toxicity at concentrations above $30 \mu \mathrm{M}$ [28]. Norbadione A also exhibits chelating properties [29], which may allow using the fruiting bodies of I. badia in the human diet processes in the future [30].

\section{Indole compounds}

A total of 140 indole compounds are present in the culinary-medicinal mushrooms [31]. Auxins are one example of indole compounds. They belong to the group of plant 
Table 1 Examples of antioxidant substances in selected mushroom species

\begin{tabular}{|c|c|c|c|c|}
\hline Antioxidants & Species & Amount & References & $\begin{array}{l}\text { Dietary reference values } \\
\text { (DRVs) }\end{array}$ \\
\hline \multirow[t]{6}{*}{ Phenolic derivatives } & Boletus edulis & $\begin{array}{l}3.5 \mathrm{~g} / 100 \mathrm{~g} \text { d.w. (as gallic } \\
\text { acid) }\end{array}$ & Alispahić et al. [21] & \\
\hline & Agaricus bisporus & $\begin{array}{l}\text { 130-620 mg/100 g d.w. (as } \\
\text { gallic acid) }\end{array}$ & Gąsecka et al. [20] & \\
\hline & Lentinula edodes & $\begin{array}{l}725 \mathrm{mg} / 100 \mathrm{~g} \text { d.w. (as gallic } \\
\text { acid) }\end{array}$ & $\begin{array}{l}\text { Yildiz et al. [18], Alispahić } \\
\text { et al. [21] }\end{array}$ & \\
\hline & & $\begin{array}{l}490 \mathrm{mg} / 100 \mathrm{~g} \text { d.w.(as gallic } \\
\text { acid) }\end{array}$ & & \\
\hline & Pleurotus ostreatus & $\begin{array}{l}960 \mathrm{mg} / 100 \mathrm{~g} \text { d.w. (as } \\
\text { chlorogenic acid); } \\
630 \mathrm{mg} / 100 \mathrm{~g} \text { d.w. (as } \\
\text { gallic acid) }\end{array}$ & $\begin{array}{l}\text { Gąsecka et al. [20], } \\
\text { Alispahić et al. [21] }\end{array}$ & \\
\hline & Morchella esculenta & $\begin{array}{l}2.5 \mathrm{~g} / 100 \mathrm{~g} \text { d.w. (as gallic } \\
\text { acid) }\end{array}$ & Yildiz et al. [18] & \\
\hline \multicolumn{5}{|l|}{ Indole compounds } \\
\hline \multirow[t]{5}{*}{ Melatonin } & Boletus edulis & $0.68 \mathrm{mg} / 100 \mathrm{~g}$ d.w & Meng et al. [36] & \\
\hline & Agaricus bisporus & $0.43-0.64 \mathrm{mg} / 100 \mathrm{~g} \mathrm{~d} . \mathrm{w}$ & Meng et al. [36] & \\
\hline & Cantharellus cibarius & $0.14 \mathrm{mg} / 100 \mathrm{~g} \mathrm{d.w}$ & Meng et al. [36] & \\
\hline & Lactarius deliciosus & $1.29 \mathrm{mg} / 100 \mathrm{~g} \mathrm{~d} . \mathrm{w}$ & Meng et al. [36] & \\
\hline & Armillaria mellea & $22.9 \mathrm{mg} / 100 \mathrm{~g} \mathrm{~d} . \mathrm{w}$ & Kała et al. [161] & \\
\hline \multirow[t]{3}{*}{ Serotonin } & Cantharellus cibarius & $29.61 \mathrm{mg} / 100 \mathrm{~g} \mathrm{~d} . \mathrm{w}$ & Muszyńska et al. [45] & \\
\hline & Armillaria mellea & $2.21 \mathrm{mg} / 100 \mathrm{~g} \mathrm{~d} . \mathrm{w}$ & $\begin{array}{l}\text { Muszyńska and Sułkowska- } \\
\text { Ziaja [50] }\end{array}$ & \\
\hline & Pleurotus eryngii & $13.18 \mathrm{mg} / 100 \mathrm{~g} \mathrm{d.w}$ & Krakowska et al. [70] & \\
\hline \multicolumn{5}{|l|}{ Carotenoids } \\
\hline$\beta$-carotene & Cantharellus cibarius & $0.79 \mu \mathrm{g} / 100 \mathrm{~g}$ & Sharma and Gautam [56] & \\
\hline Lycopene & Cantharellus cibarius & $0.33 \mu \mathrm{g} / 100 \mathrm{~g}$ & Sharma and Gautam [56] & \\
\hline Flavonoids & Boletus edulis & $\begin{array}{l}493 \mathrm{mg} / 100 \mathrm{~g} \text { (as rutin; } \\
\text { acetone extract) }\end{array}$ & Kosanić et al. [67] & \\
\hline \multirow[t]{2}{*}{ Lovastatin } & Agaricus bisporus & $56.54 \mathrm{mg} / 100 \mathrm{~g} \mathrm{d.w}$ & Chen et al. [71] & \\
\hline & Pleurotus citrinopileatus & $7.66 \mathrm{mg} / 100 \mathrm{~g}$ d.w & Krakowska et al. [70] & \\
\hline \multicolumn{5}{|c|}{ Lipid-soluble vitamins and sterols } \\
\hline \multirow[t]{2}{*}{ Ergocalciferol } & Boletus edulis & $5.87 \mathrm{mg} / 100 \mathrm{~g}$ f.w & Cardwell et al. [11] & \multirow{6}{*}{$\begin{array}{l}\text { AI Vitamin D; } 15 \mu \mathrm{g} / \mathrm{day}^{\mathrm{a}} \\
\quad(\mathrm{EFSA}, 2017)\end{array}$} \\
\hline & Cantharellus cibarius & $1.07 \mathrm{mg} / 100 \mathrm{~g}$ f.w & Cardwell et al. [11] & \\
\hline Ergosterol & Lentinula edodes & $84.9 \mathrm{mg} / 100 \mathrm{~g}$ f.w & Phillips et al. [87] & \\
\hline Ergosta-7,22-dienol & Lentinula edodes & $2.26 \mathrm{mg} / 100 \mathrm{~g} \mathrm{f.w}$ & Sułkowska-Ziaja et al. [92] & \\
\hline Ergosta-5,7-dienol & Lentinula edodes & $6.51 \mathrm{mg} / 100 \mathrm{~g}$ f.w & Sułkowska-Ziaja et al. [92] & \\
\hline Ergosta-7-enol & Lentinula edodes & $5.03 \mathrm{mg} / 100 \mathrm{~g} \mathrm{f.w}$ & Sułkowska-Ziaja et al. [92] & \\
\hline \multicolumn{5}{|c|}{ Water-soluble vitamins } \\
\hline \multirow[t]{4}{*}{ Vitamin $\mathrm{C}$} & Boletus edulis & $17 \mathrm{mg} / 100 \mathrm{~g}$ d.w & Bernaś et al. [98] & \multirow{4}{*}{$\begin{array}{l}\text { AR } 90 \text { mg/day; PRI } 110 \text { mg/ } \\
\text { day (EFSA, 2017) }\end{array}$} \\
\hline & Lentinula edodes & $25 \mathrm{mg} / 100 \mathrm{~g}$ d.w & Bernaś et al. [98] & \\
\hline & Pleurotus ostreatus & $6.8 \mathrm{mg} / 100 \mathrm{~g} \mathrm{~d} . \mathrm{w}$ & Nasiruddin et al. [97] & \\
\hline & & $20 \mathrm{mg} / 100 \mathrm{~g}$ d.w & Bernaś et al. [98] & \\
\hline \multirow[t]{5}{*}{ Vitamin $B_{1}$} & Boletus edulis & $0.94 \mathrm{mg} / 100 \mathrm{~g} \mathrm{~d} . \mathrm{w}$ & Jaworska et al. [101] & \multirow{5}{*}{$\begin{array}{l}\text { AR } 0.072 \mathrm{mg} / \mathrm{MJ} ; \text { PRI } \\
0.1 \mathrm{mg} / \mathrm{MJ} \text { (EFSA, 2017) }\end{array}$} \\
\hline & $\begin{array}{l}\text { Imleria badia }(=\text { Boletus } \\
\text { badius })\end{array}$ & $0.88 \mathrm{mg} / 100 \mathrm{~g} \mathrm{~d} . \mathrm{w}$ & Jaworska et al. [101] & \\
\hline & Lentinula edodes & $0.17 \mathrm{mg} / 100 \mathrm{~g}$ f.w & Çağlarirmak [102] & \\
\hline & Pleurotus ostreatus & $0.15 \mathrm{mg} / 100 \mathrm{~g}$ f.w & Çağlarirmak [102] & \\
\hline & Pleurotus florida & $1.08 \mathrm{mg} / 100 \mathrm{~g} \mathrm{~d} . \mathrm{w}$ & Krakowska et al. [70] & \\
\hline
\end{tabular}


Table 1 (continued)

\begin{tabular}{|c|c|c|c|c|}
\hline Antioxidants & Species & Amount & References & $\begin{array}{l}\text { Dietary reference values } \\
\text { (DRVs) }\end{array}$ \\
\hline \multirow[t]{5}{*}{ Vitamin $\mathrm{B}_{2}$} & Boletus edulis & $2.57 \mathrm{mg} / 100 \mathrm{~g}$ d.w & Jaworska et al. [101] & \multirow{5}{*}{$\begin{array}{l}\text { AR } 1.3 \mathrm{mg} / \text { day; PRI } 1.6 \mathrm{mg} / \\
\text { day (EFSA, 2017) }\end{array}$} \\
\hline & $\begin{array}{l}\text { Imleria badia }(=\text { Boletus } \\
\text { badius })\end{array}$ & $4.97 \mathrm{mg} / 100 \mathrm{~g}$ d.w & Jaworska et al. [101] & \\
\hline & Lentinula edodes & $0.21 \mathrm{mg} / 100 \mathrm{~g}$ f.w & Çağlarirmak [102] & \\
\hline & Pleurotus ostreatus & $0.22 \mathrm{mg} / 100 \mathrm{~g}$ f.w & Çağlarirmak [102] & \\
\hline & Pleurotus citrinopileatus & $2.31 \mathrm{mg} / 100 \mathrm{~g} \mathrm{~d} . \mathrm{w}$ & Krakowska et al. [70] & \\
\hline \multirow[t]{4}{*}{ Vitamin $\mathrm{B}_{3}$} & Boletus edulis & $22.89 \mathrm{mg} / 100 \mathrm{~g} \mathrm{~d} . \mathrm{w}$ & Jaworska et al. [101] & \multirow{4}{*}{$\begin{array}{l}\text { AR 1.3 mg NE/MJ; PRI } \\
\text { 1.6 mg NE/MJ; (EFSA, } \\
\text { 2017) }\end{array}$} \\
\hline & $\begin{array}{l}\text { Imleria badia }(=\text { Boletus } \\
\text { badius })\end{array}$ & $38.12 \mathrm{mg} / 100 \mathrm{~g}$ d.w & & \\
\hline & Lentinula edodes & $4.44 \mathrm{mg} / 100 \mathrm{~g}$ f.w & Çağlarirmak [102] & \\
\hline & Pleurotus ostreatus & $3.23 \mathrm{mg} / 100 \mathrm{~g}$ f.w & & \\
\hline \multirow[t]{2}{*}{ Vitamin $\mathrm{B}_{6}$} & Boletus edulis & $9 \mathrm{mg} / 100 \mathrm{~g}$ d.w & Jaworska et al. [101] & \multirow{9}{*}{$\begin{array}{l}\text { AR } 1.5 \mathrm{mg} / \text { day; PRI } 1.7 \mathrm{mg} / \\
\text { day; (EFSA, 2017) }\end{array}$} \\
\hline & $\begin{array}{l}\text { Imleria badia }(=\text { Boletus } \\
\text { badius })\end{array}$ & $209 \mathrm{mg} / 100 \mathrm{~g} \mathrm{d.w}$ & Jaworska et al. [101] & \\
\hline \multirow[t]{2}{*}{ Vitamin $\mathrm{B}_{9}$} & Lentinula edodes & $90 \mu \mathrm{g} / 100 \mathrm{~g}$ f.w & Çağlarirmak [102] & \\
\hline & Pleurotus ostreatus & $9 \mu \mathrm{g} / 100 \mathrm{~g}$ f.w & Çağlarirmak [102] & \\
\hline \multirow[t]{5}{*}{ Ergothioneine } & Boletus edulis & 727 mg/100 g d.w & Kalaras et al. [106] & \\
\hline & Cantharellus cibarius & $409 \mathrm{mg} / 100 \mathrm{~g} \mathrm{~d} . \mathrm{w}$ & Lee et al. [108] & \\
\hline & Pleurotus citrinopileatus & 129.89 mg/100 g d.w & Krakowska et al. [70] & \\
\hline & Pleurotus ostreatus & $\begin{array}{l}182.94 \mathrm{mg} / 100 \mathrm{~g} \text { d.w. } \\
\text { (Korea) }\end{array}$ & Chen et al. [71] & \\
\hline & & $\begin{array}{l}145.84 \mathrm{mg} / 100 \mathrm{~g} \text { d.w. } \\
\text { (Taiwan) }\end{array}$ & Chen et al. [71] & \\
\hline \multicolumn{5}{|l|}{ Bioelements } \\
\hline \multirow[t]{3}{*}{ Selenium } & Boletus edulis & $1.33 \mathrm{mg} / 100 \mathrm{~g} \mathrm{~d} . \mathrm{w}$ & $\begin{array}{l}\text { Mirończuk-Chodakowska } \\
\text { et al. [124] }\end{array}$ & \multirow[t]{3}{*}{ AI $70 \mu \mathrm{g} /$ day (EFSA, 2017) } \\
\hline & Agaricus bisporus & $617 \mu \mathrm{g} / 100 \mathrm{~g}$ d.w & $\begin{array}{l}\text { Mirończuk-Chodakowska } \\
\text { et al. [124] }\end{array}$ & \\
\hline & $\begin{array}{l}\text { Pleurotus ostreatus var. } \\
\text { florida }\end{array}$ & $1.29 \mathrm{mg} / 100 \mathrm{~g} \mathrm{~d} . \mathrm{w}$ & Krakowska et al. [70] & \\
\hline \multirow[t]{3}{*}{ Magnesium } & Boletus edulis & Approx. $80 \mathrm{mg} / 100 \mathrm{~g} \mathrm{d.w}$ & Zhang et al. [151] & \multirow[t]{3}{*}{ AI 350 mg/day (EFSA, 2017) } \\
\hline & Morchella esculenta & $400 \mathrm{mg} / 100 \mathrm{~g}$ d.w & Dursun et al. [153] & \\
\hline & Pleurotus citrinopileatus & $123 \mathrm{mg} / 100 \mathrm{~g}$ d.w & Krakowska et al. [70] & \\
\hline \multirow[t]{4}{*}{ Zinc } & $\begin{array}{l}\text { Imleria badia }(=\text { Boletus } \\
\text { badius })\end{array}$ & $6.06 \mathrm{mg} / 100 \mathrm{~g} \mathrm{~d} . \mathrm{w}$ & Kuziemska et al. [139] & \multirow{5}{*}{$\begin{array}{l}\text { LPI (mg/day)/PRI (mg/ } \\
\text { day); 300/9.4; 600/11.7; } \\
\text { 900/14.0; 1200/16.3 } \\
\text { (EFSA, 2017) }\end{array}$} \\
\hline & Agaricus bisporus & $2.98 \mathrm{mg} / 100 \mathrm{~g} \mathrm{~d} . \mathrm{w}$ & Kuziemska et al. [139] & \\
\hline & Lactarius deliciosus & $23.1 \mathrm{mg} / 100 \mathrm{~g} \mathrm{~d} . \mathrm{w}$ & Alonso et al. [140] & \\
\hline & Pleurotus ostreatus & $2.57 \mathrm{mg} / 100 \mathrm{~g} \mathrm{~d} . \mathrm{w}$ & Kuziemska et al. [139] & \\
\hline \multirow[t]{3}{*}{ Manganese } & Pleurotus djamor & $9.41 \mathrm{mg} / 100 \mathrm{~g} \mathrm{~d} . \mathrm{w}$ & Krakowska et al. [70] & \\
\hline & Lentinula edodes & $1.0 \mathrm{mg} / 100 \mathrm{~g} \mathrm{~d} . \mathrm{w}$ & Mallikarjuna et al. [145] & \multirow[t]{2}{*}{ AI 3 mg/day (EFSA, 2017) } \\
\hline & Pleurotus djamor & $1.13 \mathrm{mg} / 100 \mathrm{~g}$ d.w & Krakowska et al. [70] & \\
\hline
\end{tabular}

Dietary reference values: the average requirement (AR) the population reference intake (PRI) the adequate intake (AI)

LPI level of phytate intake $1 \mathrm{MJ}=238.83 \mathrm{kcal}, N E$ niacin equivalent $(1 \mathrm{mg}$ niacin $=1$ niacin equivalent $=60 \mathrm{mg}$ dietary tryptophan $), D F E$ : dietary folate equivalents. For combined intakes of food folate and folic acid, DFEs can be computed as follows: $\mu \mathrm{g}$ DFE $=\mu \mathrm{g}$ food folate $+(1.7 \times \mu \mathrm{g}$ folic acid)

${ }^{a}$ Under conditions of assumed minimal cutaneous vitamin D synthesis. In the presence of endogenous cutaneous vitamin D synthesis, the requirement for dietary vitamin $\mathrm{D}$ is lower or may between zero 


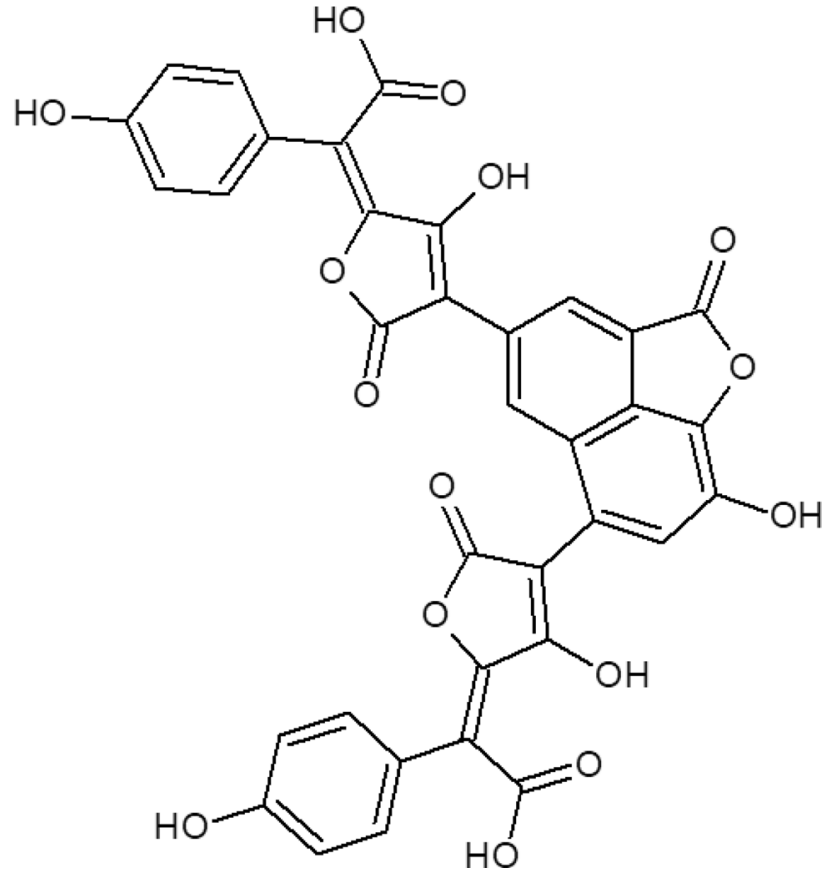

Fig. 2 Chemical structure of norbadione A

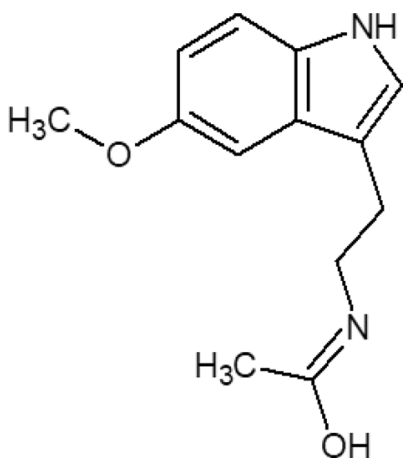

Fig. 3 Chemical structure of melatonin

hormones and have been detected in the fruiting bodies and mycelia of mushrooms [32]. The other indole compounds are tryptophan derivatives, such as melatonin, serotonin, and tryptamine [31]. To the best of our knowledge, Muszyńska et al. were the first group to research about the content of nonhallucinogenic indole compounds [33].

Among the indole compounds, melatonin (Fig. 3) is characterized by a strong antioxidant effect. This compound acts as a hormone responsible for coordinating the biological clock by regulating the circadian rhythms of sleep and wakefulness [34]. Melatonin is extremely effective in reducing oxidative stress by directly detoxification of reactive oxygen and nitrogen species and indirectly by stimulating antioxidant enzymes, as well as inhibiting the activity of pro-oxidative enzymes [35].
Melatonin is found in selected mushrooms such as L. deliciosus and B. edulis at an amount of approximately 0.0129 and $0.0068 \mathrm{mg} / \mathrm{g} \mathrm{d.w.,} \mathrm{respectively.} \mathrm{A} \mathrm{similar} \mathrm{content} \mathrm{of}$ this compound was found in $C$. cibarius (approximately $0.0014 \mathrm{mg} / \mathrm{g} \mathrm{d.w.)}$, as well as in A. bisporus cultivated on a medium enriched with zinc salts (between 0.0043 and $0.0064 \mathrm{mg} / \mathrm{g} \mathrm{d.w.)} \mathrm{[36].} \mathrm{There} \mathrm{is} \mathrm{a} \mathrm{large} \mathrm{discrepancy} \mathrm{in} \mathrm{mela-}$ tonin levels, depending not only on the species, but also on environmental conditions e.g. UV radiation (from a few $\mathrm{pg} / \mathrm{g}$ to over $20 \mu \mathrm{g} g$ and more) [37]. Stress-induced melatonin production in plants is a widely studied phenomenon. Plants exposed to adverse environmental conditions have higher levels of melatonin. Research has also shown that the production of melatonin in plants is stimulated by exposure to light. More melatonin is synthesized in some plants under greater light intensity [38]. The examples of the melatonin content in $1 \mathrm{~g}$ of dry weight in frequently consumed vegetables and fruits include: tomato-Solanum lycopersicum L. cv. Ciliegia 7.47 ng/g, Solanum lycopersicum L. cv. Optima $249.98 \mathrm{ng} / \mathrm{g}$, pepper-Capsicum annuum L. cv. Barranca $31.01 \mathrm{ng} / \mathrm{g}$, Lentils (raw) $0.5 \mathrm{ng} / \mathrm{g}$, black olive $0.01 \mathrm{ng} / \mathrm{g}$ [36, 39].

Another indole derivative, serotonin, acts as the most important endogenous neurotransmitter in the human body [40]. This compound can also evoke antioxidant activity [41]; however, exogenous serotonin is of less importance compared to the endogenous compound. Serotonin itself is not used as a medicine; instead, the compounds that intensify its neurotransmission are widely used in the pharmacotherapy of various diseases, mainly psychiatric ones (e.g., depression, obsessive-compulsive disorder) [42]. A safer way to increase the endogenous levels of serotonin, which is also considered as a "happiness hormone" [42], is to include the foods containing another indole derivative, such as L-tryptophan, in the diet [43]. The content of this metabolite ranged from 0.01 to $25.90 \mathrm{mg} / 100 \mathrm{~g} \mathrm{~d} . \mathrm{w}$. The highest L-tryptophan content was determined in extracts from unprocessed $S$. bovinus fruiting bodies $-25.90 \mathrm{mg} / 100 \mathrm{~g}$ d.w. The highest amount of L-tryptophan was found also in $C$. cibarius fruiting bodies. Among extracts of fruiting bodies subject to heat treatment, also the extract from the Suillus bovinus fruiting bodies contained the high amount of L-tryptophan-17.71 mg/100 g d.w.[43]. Therefore, the processed mushrooms, and in particular $S$. bovinus, constitute a good source of L-tryptophan in the human diet. Additionally, it should be emphasized that the presence of L-tryptophan in all fruiting bodies of mushrooms species additionally enhances their dietary values, which is of particular significance in vegetarian diet, where mushrooms rich in indole derivatives may constitute an alternative to red meat [43].

Muszyńska et al. [44] assessed the content of indole compounds in different varieties (white, brown, and portobello) of $A$. bisporus. The highest total amount of these substances 
was identified in the brown variety (over $500 \mathrm{mg} / 100 \mathrm{~g}$ d.w.). Melatonin was only found in the stipe of portobello variety $(2.3 \mathrm{mg} / 100 \mathrm{~g} \mathrm{~d}$.w.). The indole derivative that was most abundant in each variety of A. bisporus was 5-hydroxyL-tryptophan [44].

In another study conducted by Muszyńska et al. [45], the amount of indole derivatives in several mushroom species was assessed. It was found that C. cibarius and Leccinum rufum were characterized by a high content of serotonin (29.61 and $31.71 \mathrm{mg} / 100 \mathrm{~g}$ d.w., respectively). The content of kynurenic acid was estimated at $6.21 \mathrm{mg} / 100 \mathrm{~g}$ d.w. in A. bisporus, while that of kynurenine sulfate was $39.20 \mathrm{mg} / 100 \mathrm{~g}$ in L. deliciosus [45].

In a work carried out by Muszyńska et al. [46], the content of indole compounds was compared in the fruiting bodies and mycelium obtained from the in vitro cultures of $C$. cibarius. The authors found that the level of serotonin was similar in fruiting bodies and mycelium (17.61 and $20.49 \mathrm{mg} / 100 \mathrm{~g}$ d.w., respectively). However, a large difference was found for the level of 5-hydroxy-L-tryptophan (only $0.01 \mathrm{mg} / 100 \mathrm{~g}$ d.w. in fruiting bodies and $12.52 \mathrm{mg} / 100 \mathrm{~g}$ d.w. in mycelium obtained from in vitro cultures) and kynurenine sulfate $(3.62 \mathrm{mg} / 100 \mathrm{~g}$ d.w. in fruiting bodies and $35.34 \mathrm{mg} / 100 \mathrm{~g}$ d.w. in mycelium). The content of melatonin in fruiting bodies was estimated at $0.11 \mathrm{mg} / 100 \mathrm{~g}$ d.w., while in the mycelium the content was only $0.01 \mathrm{mg} / 100 \mathrm{~g}$ d.w.[46].

Indole compounds were also studied in B. edulis, $P$. ostreatus, and Suillus luteus in another work of Muszyńska et al. [47]. In S. luteus, as high as $34.11 \mathrm{mg} / 100 \mathrm{~g}$ d.w. of serotonin content was determined. Melatonin was detected in B edulis $(0.68 \mathrm{mg} / 100 \mathrm{~g} \mathrm{d.w.})$ and $S$. luteus $(0.71 \mathrm{mg} / 100 \mathrm{~g}$ d.w.), while kynurenine sulfate was present only in $S$. luteus (19.57 mg/100 g d.w.).

Cooking is one of the ways to prepare mushrooms for eating. However, this process may influence the level of certain compounds present in them [48, 49]. Muszyńska et al. [50] analyzed the composition of indole derivatives in different Basidiomycota species before and after thermal processing. The main tendency showed that the fruiting bodies subject to heat treatment were found to contain approximately twofold lower total content of indole compounds. The highest total content of indole compounds was determined in the fruiting bodies of $C$. cibarius, L. deliciosus, S. bovinus, both unprocessed and heat treated [48-50]. The effect of elevated temperature during cooking on the levels of indole compounds is, however, not clear. The decrease is probably due to the decomposition of these compounds under high temperature, because they are thermolabile. The increase in the amount of some compounds may be associated with thermally induced changes in other compounds. The results also showed that serotonin was only found in unprocessed mushrooms $(6.52 \mathrm{mg} / 100 \mathrm{~g}$ d.w. in P. ostreatus, $10.14 \mathrm{mg} / 100 \mathrm{~g}$ d.w. in B. edulis, $18.42 \mathrm{mg} / 100 \mathrm{~g}$ d.w. in L. deliciosus, and $29.61 \mathrm{mg} / 100 \mathrm{~g}$ d.w. in $C$. cibarius). In addition, kynurenic derivatives were found only in the mushrooms that were not subjected to boiling: the highest content of kynurenine sulfate was observed in L. deliciosus (39.2 mg/100 g d.w.), while kynurenic acid was detected only in thermally unprocessed B. badius $(1.57 \mathrm{mg} / 100 \mathrm{~g}$ d.w.). An opposite trend was observed in the case of melatonin in $C$. cibarius. The amount of this compound was as low as $0.14 \mathrm{mg} / 100 \mathrm{~g}$ d.w. in the sample not subjected to boiling; while in the thermally processed sample, the content was $4.40 \mathrm{mg} / 100 \mathrm{~g}$ d.w.[46].

\section{Carotenoids}

Carotenoids are organic compounds with a tetraterpene structure and have 40 carbon atoms [51]. Their antioxidant activity consists primarily in the formation of adducts with free radicals derived from linolenic acid and the reduction of $\mathrm{Fe}^{3+}$ to $\mathrm{Fe}^{2+}$ [52]. $\beta$-Carotene (Fig. 4), which is also present in mushrooms, is primarily responsible for these actions of carotenoids [53]. Carotenoid compounds have been identified to play an important role in protection against diseases associated with oxidative stress, including those of the nervous system and circulatory system, as well as various types of cancers [51]. Apart from $\beta$-carotene, the other examples of carotenoids are lycopene, lutein, zeaxanthin, cryptoxanthin, and phytoene [54]. These compounds are usually red or orange in color but can also be colorless. Importantly, they usually do not degrade during cooking or baking [55].

In the work of Sharma and Gautam [56], the content of carotenoids, including $\beta$-carotene and lycopene, in 20 species was determined. Among them, the highest amount of $\beta$-carotene was determined in the following species: A. arvensis $(0.75 \mu \mathrm{g} / 100 \mathrm{~g})$, Agaricus comtulus $(0.70 \mu \mathrm{g} / 100 \mathrm{~g})$, Amanita caesarea $(0.71 \mu \mathrm{g} / 100 \mathrm{~g})$, C. cibarius $(0.79 \mu \mathrm{g} / 100 \mathrm{~g})$, Lentinula cladopus $(0.75 \mu \mathrm{g} / 100 \mathrm{~g})$, and Pleurotus cystidiosus $(0.79 \mu \mathrm{g} / 100 \mathrm{~g})$. The highest concentration of lycopene was found in A. arvensis $(0.38 \mu \mathrm{g} / 100 \mathrm{~g})$, C. cibarius $(0.33 \mu \mathrm{g} / 100 \mathrm{~g})$, and Lactarius pubescens $(0.33 \mu \mathrm{g} / 100 \mathrm{~g})$ [56].

Barros et al. [57] studied the antioxidant activity fruiting bodies of another Lactarius species, namely L. piperatus, in different maturity stage. It was found that the highest antioxidant compounds contents were found in the mature stage with the immature spores ( $\beta$-carotene: $33.78 \mu \mathrm{g} / \mathrm{g}$ of extract, lycopene: $13.04 \mu \mathrm{g} / \mathrm{g}$ of extract) [57]. Another report on the presence of carotenoids in mushrooms was presented by Ribeiro et al. [58]. Using the HPLC-DAD (high-performance liquid chromatography coupled to a diode array detector) method, the authors confirmed that only one carotene compound, $\beta$-carotene, was found in only one species (C. cibarius) among the 17 species tested. The report indicated that the orange color of $C$. cibarius is at least partly 
Fig. 4 Chemical structure of $\beta$-carotene

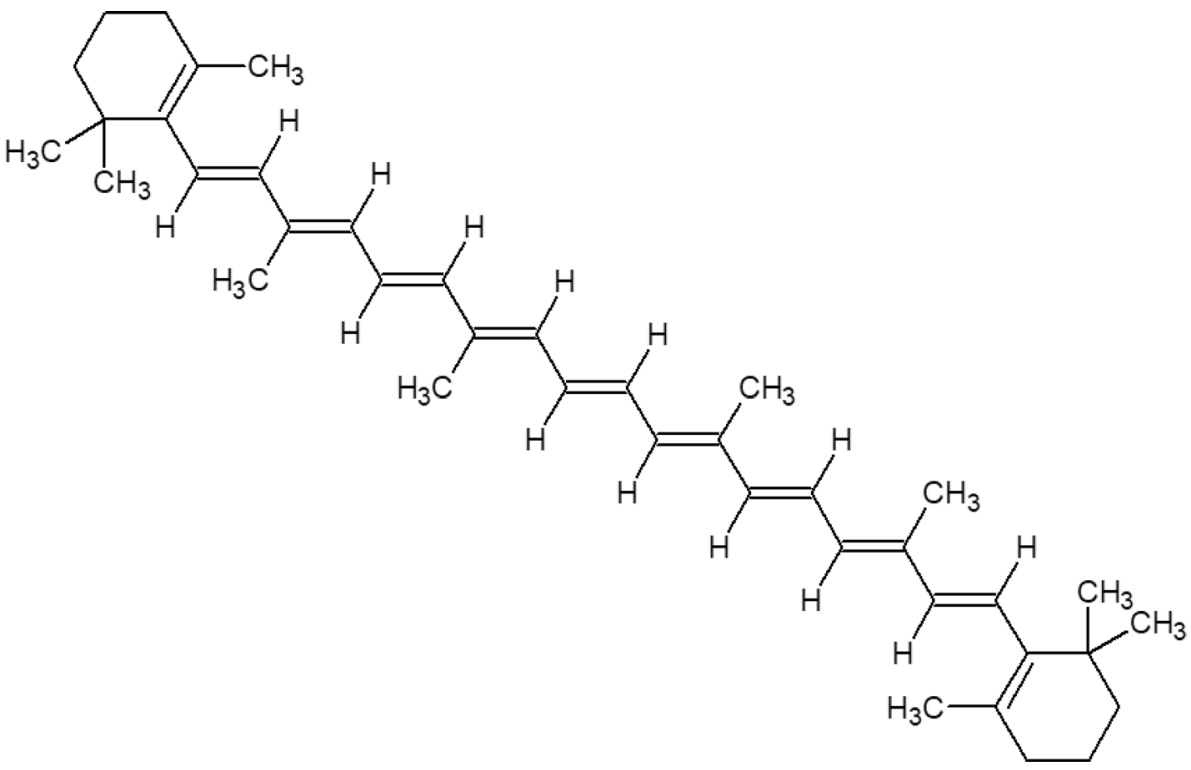

due to the presence of $\beta$-carotene [58]. In a work authored by Kozarski et al. [59], the amounts of antioxidant compounds in the methanol extract from $C$. cibarius were assessed: the contents of $\beta$-carotene and lycopene level were equal to $112.2 \mu \mathrm{g} / \mathrm{g} \mathrm{dw}$, respectively.

\section{Flavonoids}

There are conflicting reports regarding the presence of flavonoids in the fruiting bodies of mushrooms. Many authors have confirmed the presence of flavonoid compounds and determined their content in mushrooms [17, 60], but in the work of Gil-Ramírez et al. [61], the presence of flavonoids in mushrooms is denied. However, as a multitude of studies have been carried out on the presence of these compounds in the fruiting bodies of mushrooms and determined their content, it should be assumed that flavonoids occur in many representatives of the fungal kingdom. In the recent work authored by Shao et al. [62] seven core genes which are involved in the biosynthesis of flavonoids in Sanghuangporus sanghuang were found.

Some authors classify flavonoids as a representative of phenolic compounds [63]. However, due to their very large number (about 8000) [64], it seems reasonable to describe flavonoids separately. In terms of chemical structure, these compounds can be classified as phenol derivatives, since they have at least one hydroxyl group [63]. The skeletal structure of flavonoids contains a three-ring flavone, and very often, they occur as aglycons in combination with sugars, resulting in the formation of glycosides [60, 65]. Flavonoids exert antioxidant activity due to the presence of hydroxyl groups, as is the case with phenolic compounds [64].
Some representatives of flavonoids are quercetin, hesperidin, and catechin. Anthocyanidins also belong to this group of antioxidants [66].

In one of their works [17], Butkhup et al. analyzed the content of flavonoids in various species of mushrooms obtained from northeastern Thailand. The content of these compounds, expressed as catechin, was found to be the highest in the following species: Russula luteotacta $(2.09 \mathrm{mg} / \mathrm{g}$ d.w.), Termitomyces fuliginosus (2.19 mg/g d.w.), T. clypeatus (5.10 mg/g d.w.), V. volvacea (3.45 mg/g d.w.), and Lentinus polychrous $(2.27 \mathrm{mg} / \mathrm{g} \mathrm{d.w.)}$.

Kosanić et al. [67] compared the content of flavonoids in three species of mushrooms, namely Boletus aestivalis, B. edulis, and Leccinum carpini. Acetone and methanol extracts were analyzed, and it was found that a higher content of flavonoid, in terms of rutin, was present in the extracts obtained using acetone. The flavonoid content in $B$. edulis was $4.93 \mu \mathrm{g} / \mathrm{mg}$ extract; in B. aestivalis, was $3.20 \mu \mathrm{g} /$ $\mathrm{mg}$ extract; and in L. carpini, was $1.86 \mu \mathrm{g} / \mathrm{mg}$ extract [67].

Barros et al. [68] assessed the content of flavonoids in eight species of mushrooms. Among them, A. silvaticus was characterized by the highest level of those compounds (3.4 mg/g extract, calculated as (+)-chatequin); while in Agaricus silvicola and Marasmius oreades, the total flavonoid content was $2.87 \mathrm{mg} / \mathrm{g}$ extract and $2.26 \mathrm{mg} / \mathrm{g}$ extract, respectively.

\section{Lovastatin}

Apart from the compounds described in the previous sections, there is another molecule originating from mushrooms called lovastatin $[69,70]$. It acts as a precursor for a group of medicines used in the treatment of various diseases including atherosclerosis and dyslipidemia. Lovastatin (Fig. 5) is 


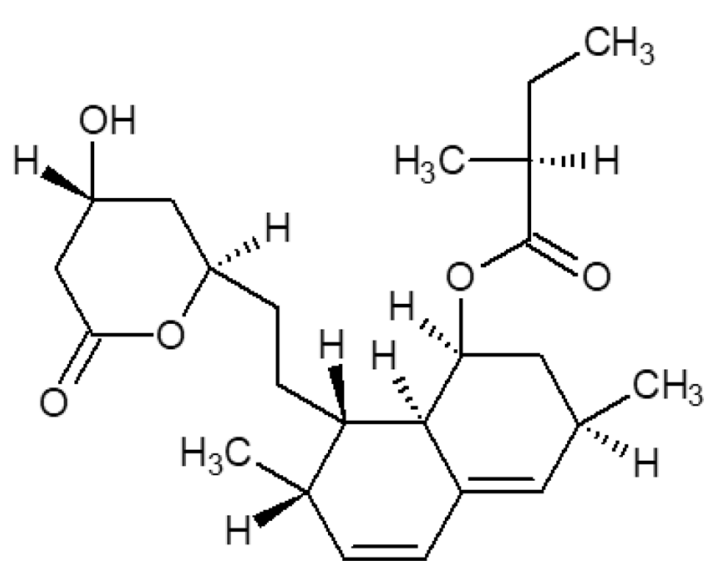

Fig. 5 Chemical structure of lovastatin

an inhibitor of the enzyme 3-hydroxy-3-methyl-glutarylcoenzyme A reductase. The class of medicines developed from lovastatin is commonly known as statins and is characterized by the same mechanism of action as their precursor. However, these drugs evoke many pleiotropic effects, one of which is antioxidant activity.

Chen et al. [71] studied over 20 species of mushrooms to assess their content of lovastatin. The authors found that the fruiting bodies of P. ostreatus (from Japan), A. bisporus, and $B$. edulis were the richest sources of this compound and contained $606.5,565.4$, and $327.3 \mathrm{mg} / \mathrm{kg}$ d.w., respectively. Interestingly, two other samples of $P$. ostreatus, from Korea and Taiwan, were characterized by a far lesser content of lovastatin (165.3 and $216.4 \mathrm{mg} / \mathrm{kg}$ d.w., respectively); while some species lacked the compound (L. edodes, Grifola frondosa, and Pleurotus salmoneostramineus [71].

\section{Lipid-soluble vitamins}

\section{Tocopherols}

Tocopherols are collectively referred to as vitamin E. They are made of two rings (chromanol skeleton) and have a side chain containing three isoprene units (15 carbon atoms) [72]. Tocopherols are very potent antioxidants and protect lipids (including polyunsaturated fatty acids) against peroxidation, thereby interrupting the formation of ROS in free radical reactions [73]. Reports imply that the combination of vita$\min \mathrm{E}$ and cholinesterase inhibitors exerts a more beneficial therapeutic effect (due to the antioxidant activity) in the treatment of Alzheimer's disease compared to their individual use [72].

Vamanu and Nita assessed the content of tocopherols in different types of extracts obtained from $B$. edulis [74]. $\alpha$-Tocopherol was not observed in any of the ethanol, methanol, or aqueous extracts (extracted with cold or hot water) tested. $\delta$-Tocopherol was detected only in the alcohol extracts $(0.075 \mathrm{mg} / 100 \mathrm{~g}$ ethanol extract and $0.006 \mathrm{mg} / 100 \mathrm{~g}$ methanol extract). By contrast, $\gamma$-tocopherol was present in each of the analyzed extracts; its content was the highest in the ethanol extract $(0.711 \mathrm{mg} / 100 \mathrm{~g}$ extract $)$, while it was much less in methanol $(0.024 \mathrm{mg} / 100 \mathrm{~g}$ extract $)$ and aqueous extracts (less than $0.010 \mathrm{mg} / 100 \mathrm{~g}$ extract) [74].

Heleno et al. [75] examined the content of tocopherol in various species of mushrooms growing in Portugal. They found the highest amounts of all forms of tocopherols in Laccaria laccata ( $8.04 \mu \mathrm{g} / \mathrm{g}$ d.w.), Clitocybe alexandri (3.55 $\mu \mathrm{g} / \mathrm{g}$ d.w.), Fistulina hepatica (2.26 $\mu \mathrm{g} / \mathrm{g}$ d.w.), and Laccaria amethystina (1.98 $\mu \mathrm{g} / \mathrm{g}$ d.w.).

There are also data available on the content of tocopherol in mushrooms growing in the southern hemisphere. Toledo et al. [76] determined the level of vitamin $E$ in the fruiting bodies of mushrooms originating from Nothofagus (southern beech) forests in Argentina. They observed that the content was the highest in the following species: Cortinarius magellanicus (89.68 $\mu \mathrm{g} / 100 \mathrm{~g}$ d.w.), Lepista nuda $(38.24 \mu \mathrm{g} / 100 \mathrm{~g}$ d.w.), and Fistulina endoxantha $(=F$. hepatica; $35.01 \mu \mathrm{g} / 100 \mathrm{~g}$ d.w.) [76]. It is worth noting that in the same species of mushroom growing in Argentina ( $F$. endoxantha $=F$. hepatica), the total content of vitamin $\mathrm{E}$ is more than six times lower compared to that in the species originating from Portugal.

Bouzgarrou et al. [77] proposed an interesting idea for the addition of antioxidants to yogurt, primarily $\alpha$-tocopherol. They stated that instead of adding the substance itself, it would be better to add the mycelial extract of G. lucidum. This is because although this mushroom is considered inedible, it is not poisonous and has a high content of tocopherol and other antioxidants.

\section{Vitamin D and other sterols}

Vitamin D exists in two forms: cholecalciferol (vitamin $\mathrm{D}_{3}$ ) and ergocalciferol (vitamin $\mathrm{D}_{2}$ ). Although both have a similar bioavailability [78], they originate from different sources: cholecalciferol is present in foods of animal origin, while ergocalciferol is found in plants and mushrooms $[11,79,80]$. Ergocalciferol is produced from provitamin $D_{2}$ (ergosterol) under the action of UV [81]. Vitamin $\mathrm{D}_{2}$ has antioxidant properties and has been shown to protect lipids against peroxidation [82]. Due to the widespread deficiency of vitamin $\mathrm{D}$ in the general population [83,84], it is justified that this vitamin can be supplemented, for example, through the increased consumption of fruiting mushrooms.

Huang et al. [85] examined the effect of UV-B irradiation on the content of ergocalciferol in 11 species, which included those of Agaricus, Agrocybe, Auricularia, Hypsizygus, Lentinula, Pholiota, and Pleurotus. Before irradiation, the content of vitamin $\mathrm{D}_{2}$ in the fresh fruiting 
bodies was estimated to be around $3.93 \mu \mathrm{g} / \mathrm{g}$ d.w. (Pleurotus citrinopileatus); while, the compound was not detected in A. blazei, Auricularia polytricha, and Pholiota nameko. However, after $2 \mathrm{~h}$ of exposure, a much larger amount of ergocalciferol (between $15.06 \mu \mathrm{g} / \mathrm{g}$ d.w. in Hypsizygus marmoreus and $208.65 \mu \mathrm{g} / \mathrm{g}$ d.w. in P. citrinopileatus) was determined [85]. In addition, the UV-B irradiation of both the fruiting bodies and mycelium caused a change in the content of other substances with antioxidant activity such as ergothioneine, flavonoids, and phenolic compounds, and in vitro tests confirmed a slight increase in their reducing power and chelating properties. However, the free radical scavenging activity of the fruiting bodies and mycelium was found to be merely decreased [85].

The phenomenon of increase in the content of vitamin $\mathrm{D}_{2}$ under the influence of $\mathrm{UV}$ radiation is widely described in the literature. In an extensive work, Taofiq et al. [86] confirmed the beneficial effect of irradiation on increasing the amount of ergocalciferol in mushrooms.

According to the review of Cardwell et al. [11], in the fresh samples of Cantharellus tubaeformis, C. cibarius, and B. edulis mushrooms (not subjected to irradiation processes), the content of ergocalciferol was around $30 \mu \mathrm{g} / \mathrm{g}$ fresh weight (f.w.), 10.7 and $58.7 \mu \mathrm{g} / \mathrm{g}$ f.w., respectively. By contrast, A. bisporus sold in large shopping centers was found to be almost depleted of vitamin $\mathrm{D}_{2}$ : only less than $1 \mu \mathrm{g}$ of the substance was found in a 100-g mass of fresh mushrooms [11].

Phillips et al. [87] determined the content of vitamin $\mathrm{D}_{2}$ in mushrooms available on the American market. Among the samples of mushrooms not exposed to UV radiation, the largest amount of ergocalciferol was determined in the genera Cantharellus $(2.18-8.41 \mu \mathrm{g} / 100 \mathrm{~g}$ f.w.) and Morchella (4.52-6.26 $\mu \mathrm{g} / 100 \mathrm{~g}$ f.w.). By contrast, different varieties of A. bisporus (cremini, portobello) were found to contain a very small amount of vitamin $\mathrm{D}_{2}$, not exceeding $0.77 \mu \mathrm{g} / 100 \mathrm{~g}$ f.w. On the other hand, portobello mushrooms exposed to UV radiation were characterized by a higher level of this compound ranging from 3.36 to $20.9 \mu \mathrm{g} / 100 \mathrm{~g}$ f.w. [87]. The US Department of Agriculture provided evidence that UV-exposed mushrooms contain substantial amounts of vitamin D [88] and this is practical procedure used by USA commercial company which produces $A$. bisporus enriched with vitamin $\mathrm{D}_{2}$ [89].

To sum up, mushrooms in which the content of vitamin $\mathrm{D}_{2}$ is increased by UV radiation can serve as an attractive functional food, while the commercially available mushrooms which are most popular do not constitute a good source of this substance.

Similar to $\mathrm{D}_{2}$, another form of vitamin $\mathrm{D}$ known as $\mathrm{D}_{4}[90,91]$ or dihydroergocalciferol is also detected in mushrooms.
Apart from vitamin $\mathrm{D}$, the other sterols present in mushrooms are ergosta-7,22-dienol, ergosta-5,7-dienol, and ergosta-7-enol [92]. In the work of Sułkowska-Ziaja et al. [92], L. edodes was reported to contain on average $2.26 \mathrm{mg} / 100 \mathrm{~g}$ f.w. of ergosta-7,22-dienol, $6.51 \mathrm{mg} / 100 \mathrm{~g}$ f.w. of ergosta-5,7-dienol, and $5.03 \mathrm{mg} / 100 \mathrm{~g}$ f.w. of ergosta-7-enol.

The previously mentioned study of Phillips et al. [87] also assessed the amount of sterols other than vitamin $\mathrm{D}_{2}$ in mushrooms. The authors reported that $L$. edodes contained $84.9 \mathrm{mg} / 100 \mathrm{~g}$ f.w. of ergosterol; while in $G$. fron$d o s a$, the level of ergosterol equaled $79.2 \mathrm{mg} / 100 \mathrm{~g}$ f.w. The highest amount of ergosta-7,22-dienol, ergosta-5,7-dienol, and ergosta-7-enol was found in A. bisporus portobello $(2.57 \mathrm{mg} / 100 \mathrm{~g}$ f.w.), Flammulina velutipes $(16.5 \mathrm{mg} / 100 \mathrm{~g}$ f.w.), and $L$. edodes (5.03 mg/100 g f.w.), respectively (Phillips et al., 2011). The highest ergosterol contents determined for selected medicinal mushrooms from Pleurotus genus reached 64.56 and $37.96 \mathrm{mg} / 100 \mathrm{~g}$ d.w. for fruiting bodies and mycelia from in vitro cultures of Pleurotus djamor, respectively [70].

\section{Water-soluble vitamins}

\section{Vitamin C}

Vitamin C (L-ascorbic acid) is one of the most important antioxidants present in cells and plasma [60]. It acts as an electron donor and prevents the damage caused by pro-oxidative substances (e.g., hydrogen peroxide) [93]. In addition to performing several important functions in the human body (e.g., participating in collagen biosynthesis [94], L-ascorbic acid plays a significant role as a component of the ascorbate peroxidase enzyme found in some plants, which protects them from the effects of free radicals resulting, for example, from photosynthesis or photorespiration [95].

Nakalembe et al. [96] examined the content of vitamin $\mathrm{C}$ in mushrooms growing in Uganda. The largest amount of L-ascorbic acid was recorded in the species Volvariella speciosa $(21.40 \mathrm{mg} / 100 \mathrm{~g} \mathrm{~d} . \mathrm{w}$.) which were growing at a subhumid site, Polyporus tenuiculus ( $18.10 \mathrm{mg} / 100 \mathrm{~g}$ d.w.) growing at a humid site, and T. clypeatus $(17.80 \mathrm{mg} / 100 \mathrm{~g}$ d.w.) growing at a subhumid site.

Furthermore, Nasiruddin et al. [97] compared the content of nutrients in two species of Pleurotus genus: Pleurotus hiking and $P$. ostreatus. They estimated the content of ascorbic acid as 24.68 and $68.06 \mathrm{mg} / \mathrm{kg}$ d.w., respectively.

Bernaś et al. [98] determined the content of vitamin $\mathrm{C}$ in mushrooms growing in Poland and reported that $L$. edodes $(25 \mathrm{mg} / 100 \mathrm{~g}$ d.w.) contained the highest amount of ascorbic acid, while a smaller amount was present in P. ostreatus and B. edulis (20 and $17 \mathrm{mg} / 100 \mathrm{~g}$ d.w., respectively). 


\section{Vitamin B}

Vitamin B complex has antioxidant properties, but reports indicate that it exerts pro-oxidative effects as well [99]. Mushrooms are a very good source of $B$ vitamins such as $B_{1}$, $\mathrm{B}_{2}, \mathrm{~B}_{3}, \mathrm{~B}_{6}$, and $\mathrm{B}_{12}$ [60]. Compared to plants, fungi have a higher content of $\mathrm{B}$ vitamins [100]. It is assumed that $100 \mathrm{~g}$ of mushrooms can satisfy $2-9,10-34,7-12$, and $1-8 \%$ of the daily demand for vitamins $\mathrm{B}_{1}, \mathrm{~B}_{2}, \mathrm{~B}_{3}$, and $\mathrm{B}_{6}$, respectively. Fresh mushrooms are characterized by a higher content of $\mathrm{B}$ vitamins than those subjected to drying [101].

Çağlarirmak [102] stated in her work that the most important nutrients in L. edodes and P. ostreatus are vitamins $\mathrm{B}_{1}$, $\mathrm{B}_{2}$, and $\mathrm{B}_{3}$ and folic acid (vitamin $\mathrm{B}_{9}$ ). Between the two species tested, $L$. edodes contained more folic acid (up to $90 \mu \mathrm{g} / 100 \mathrm{~g}$ f.w.). The content of vitamin $\mathrm{B}_{9}$ in P. ostreatus was found to be $9 \mu \mathrm{g} / 100 \mathrm{~g}$ f.w. However, the amount of thiamine in both species of mushrooms was similar (L. edodes: up to $0.17 \mathrm{mg} / 100 \mathrm{~g}$ f.w., P. ostreatus: $0.15 \mathrm{mg} / 100 \mathrm{~g}$ f.w.). In addition, both species had a comparable amount of vitamins $\mathrm{B}_{2}$ and $\mathrm{B}_{3}$ (L. edodes: $0.21 \mathrm{mg}$ of riboflavin $/ 100 \mathrm{~g}$ f.w. and $4.44 \mathrm{mg}$ of niacin $/ 100 \mathrm{~g}$ f.w.; P. ostreatus: 0.22 and $3.23 \mathrm{mg} / 100 \mathrm{~g}$ f.w., respectively) [102].

Jaworska et al. examined the content of B vitamins in I. badia and B. edulis [100]. The tests conducted by the authors confirmed the previous observations of the reduction in the amount of vitamins in mushrooms during the drying process. The content of the following $B$ vitamins was determined in B. edulis (calculated per $100 \mathrm{~g}$ d.w.): $\mathrm{B}_{1}$ : $0.94 \mathrm{mg}, \mathrm{B}_{2}: 2.57 \mathrm{mg}, \mathrm{B}_{3}: 22.89 \mathrm{mg}$, and $\mathrm{B}_{6}: 9 \mathrm{mg}$ [100]. In the fruiting bodies of $I$. badia, the amount of vitamins $\mathrm{B}_{1}$, $\mathrm{B}_{2}, \mathrm{~B}_{3}$, and $\mathrm{B}_{6}$ was estimated as follows (per $100 \mathrm{~g} \mathrm{d.w.):} \mathrm{B}_{1}$ : $0.88 \mathrm{mg}, B_{2}: 4.97 \mathrm{mg}, B_{3}: 38.12 \mathrm{mg}$, and $B_{6}: 209 \mathrm{mg}$ [100]. It is worth noting that $I$. badia showed a very high content of vitamin $\mathrm{B}_{6}$.

\section{Another mushroom organic compounds with antioxidants activity}

\section{Ergothioneine}

Ergothioneine (Fig. 6), a nonprotein amino acid, is a thiourea derivative of histidine [103]. Cells having a less amount of this compound are more prone to the effects of oxidative damage, including lipid peroxidation and defects in the oxidation of DNA or protein [103, 104]. Ergothioneine is present in mushrooms, seeds of plants, and some bacteria. It is also found in the cells of higher organisms in large numbers due to the process of accumulation, during which the compound is transported by OCTN1 carrier for organic cations $[104,105]$. In the human body, ergothioneine occurs in the highest concentration in the erythrocytes, kidneys,

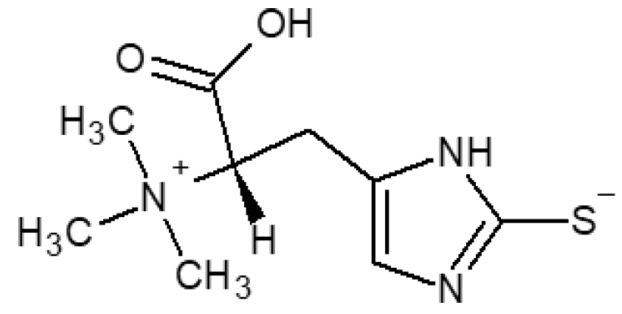

Fig. 6 Chemical structure of ergothioneine

liver, eyes, and semen [106]. The antioxidant effect of ergothioneine is believed to be associated with the stimulation of glutathione formation as well as the effect on the signal transduction pathways taking place in the cells, including NF-kB [106, 107].

Kalaras et al. [106] determined the content of ergothioneine in several species of fruiting mushrooms in their study. They found the highest amount in B. edulis ( $7.27 \mathrm{mg} / \mathrm{g} \mathrm{d}$.w.), P. citrinopileatus (3.94 mg/g d.w.), and Agrocybe aegerita ( $2.56 \mathrm{mg} / \mathrm{g}$ d.w.). A much lower amount of the compound, not exceeding $0.5 \mathrm{mg} / \mathrm{g}$ d.w., was observed in different varieties of A. bisporus [106].

Lee et al. [108] determined the level of ergothioneine in the mushroom species growing in South Korea. The highest content of this amino acid was observed in $L$. nuda (5.54 mg/g d.w.), Hygrophorus russula (4.98 mg/g d.w.), and C. cibarius $(4.09 \mathrm{mg} / \mathrm{g}$ d.w.). The content of ergothioneine in B. edulis was not studied; however, in another representative of this species (Boletus auripes), the level of ergothioneine was calculated as $2.4 \mathrm{mg} / \mathrm{g}$ d.w.[108].

In addition, the content of ergothioneine in fruiting bodies was assessed by Chen et al. [71]. A high concentration of this compound was found in the species $P$. citrinopileatus $(2850.7 \mathrm{mg} / \mathrm{kg}$ d.w.). This observation was similar to the finding of Kalaras et al. [106], who established the amount of ergothioneine in the same species at $3.94 \mathrm{mg} / \mathrm{g}$ d.w. (i.e., $3940 \mathrm{mg} / \mathrm{kg}$ d.w.) as well as in P. ostreatus (sample from Korea: $1829.4 \mathrm{mg} / \mathrm{kg}$ d.w.; sample from Taiwan: $1458.4 \mathrm{mg} / \mathrm{kg}$ d.w.). The research carried out on mushrooms from Pleurotus genus revealed the highest content of ergothioneine in fruiting bodies of Pleurotus citrinopileatus $(129.89 \mathrm{mg} / 100 \mathrm{~g} \mathrm{~d}$.w.) and in mycelia from in vitro cultures of Pleurotus citrinopileatus (128.35 mg/100 g d.w.) [70].

\section{Benzoquinones}

Benzoquinones are substances derived from $p$-benzoquinone, which include agaridoxin, atromentin, and polyporic acid (Fig. 7) [109]. These compounds display antioxidant activity due to the presence of conjugated double bonds in their structure. In addition, they are characterized by other beneficial properties. For instance, agaridoxin exhibits 
Fig. 7 Chemical structures of agaridoxin (a), atromentin (b), and polyporic acid (c)<smiles>N=C(O)CC[C@H](Nc1ccc(O)c(O)c1)C(=O)O</smiles>

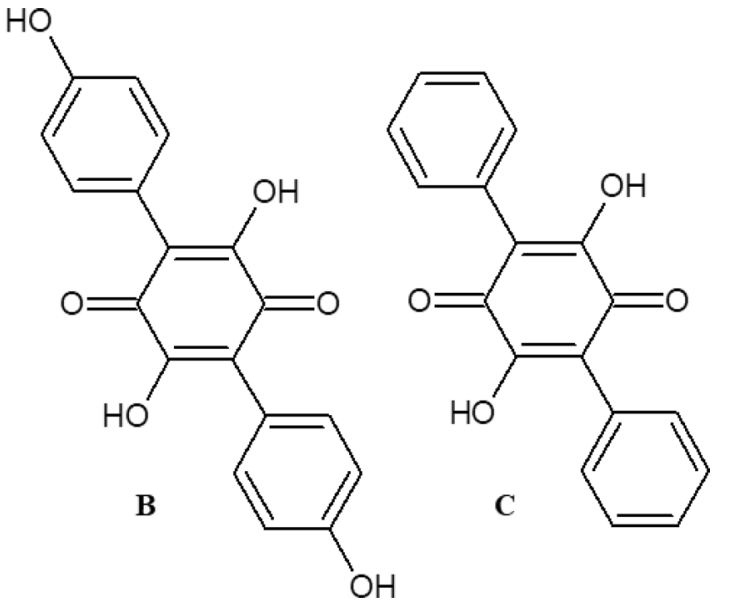

bactericidal activity against Staphylococcus aureus [110]. Atromentin belongs to the group of dyes present in Basidiomycota mushrooms and imparts them a brown color. It is also present, among others, in Paxillus atrotomentosus. This compound poses antithrombotic effects [110, 111], as well as myorelaxant effects on smooth muscles [112], and also inhibits enoyl-ACP reductase (FabK) enzyme exerting antibacterial activity on Streptococcus pneumoniae [113]. Polyporic acid was first isolated in the 19th century from Hapalopilus nidulans. This compound acts as an inhibitor of the enzyme dihydroorotate dehydrogenase and has been reported by Burton and Cain [114] to evoke antileukemic activity in mice.

\section{Azulenes}

Azulenes, belonging to the class of terpenoids, also exhibit antioxidant activity [115, 116]. Guaiazulene derivative, (7-isopropenyl-4-methylazulen-1-yl)methyl stearate (Fig. 8), is a blue dye which is responsible for the blue color of Lactarius indigo [117]. In addition, sesquiterpenoid compounds having an azulene skeleton were identified in L. deliciosus. One of the compounds, 7-acetyl-4-methylazulene-1-carbaldehyde, was found to show antibacterial activity against S. aureus [118]. Another azulene derivative, 7-acetyl4-methylazulene-1-carboxylic acid, was detected in Lactarius salmonicolor [115].
Fig. 8 Chemical structure of (7-isopropenyl-4-methylazulen1-yl)methyl stearate

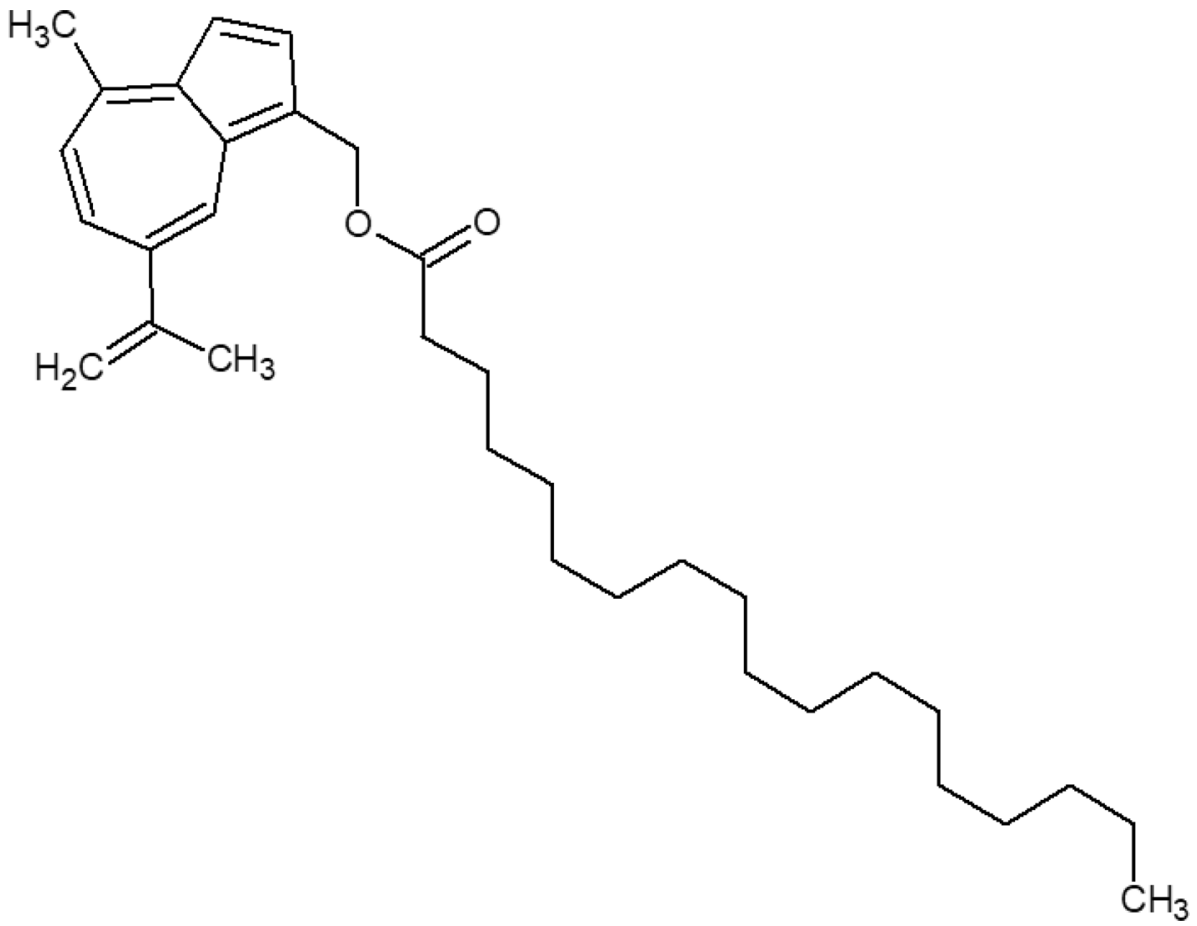




\section{Bioelements}

\section{Selenium}

Selenium is one of the essential microelements [119]. Its deficiencies are common in the general population. In addition, soils in Poland and Europe are often characterized by a low content of this element [120,121]. A very low level of selenium in the body can promote the development of serious diseases such as heart ailments and cancer [119]. Selenium is known to play an important role in many body functions. It is a part of selenocysteine, which is considered as the 21 st amino acid [119]. Glutathione peroxidase, which protects the cells against the harmful effects of peroxides, contains, among others, selenocysteine [122]. Thioredoxin reductase and iodothyrosine deiodinase are the other selenium-containing enzyme systems [123].

The latest study by Mirończuk-Chodakowska et al. has focused on the content of selenium in mushrooms growing in Poland [124]. The results of the study showed that the largest amount of this element was present in $B$. edulis (13.3 $\mu \mathrm{g} / \mathrm{g}$ d.w.), while in A. bisporus the content was $6.17 \mu \mathrm{g} / \mathrm{g}$ d.w. and in Macrolepiota procera it was $2.93 \mu \mathrm{g} / \mathrm{g}$ d.w.[124]. In the other species of mushrooms tested, the level of this element was not found to exceed $2 \mu \mathrm{g} / \mathrm{g}$ d.w. (S. luteus: $1.64 \mu \mathrm{g} / \mathrm{g}$ d.w., L. deliciosus: $1.46 \mu \mathrm{g} / \mathrm{g}$ d.w.) [124].

Zięba et al. [125] studied the impact of biofortification of Pleurotus eryngii mycelium and fruiting bodies in $\mathrm{Zn}$ and Se salts to the effectiveness of their accumulation and content of organic compounds include phenolic compounds and lovastatin. The enrichment of growing media led to higher content of these metals in the mycelium and fruiting bodies with a diverse effect regarding other chemical constituents.[125].

Zhou et al. [126] studied the absorption of inorganic selenium in the fruiting bodies of $L$. edodes and its transformation into organic derivatives, which was characterized by better digestibility. The authors reported that selenomethionine is the main organic derivative of selenium, which, like selenocysteine, has strong antioxidant properties [119].

\section{Zinc}

The antioxidant properties of zinc and its ability to inhibit the formation of free radicals are well documented in the literature $[127,128]$. This element, which belongs to the group of transition metals, is found in about 300 enzymes [129], including those exhibiting antioxidant effects such as zinc-copper superoxide dismutase [130]. The specified enzyme protects the purine bases in DNA against oxidative stress caused by superoxide compounds, and thus, superoxide dismutase is considered as one of the targets to prevent cancer transformation. Zinc also participates in the production of proteins with antioxidant activity (e.g., thionein) [131]. In addition, this element inhibits the activity of NADPH oxidase, thereby preventing the production of ROS, which is similar to the action of the abovementioned superoxide. Furthermore, due to its antagonistic activity toward the NMDA receptors, zinc prevents the influx of calcium into neurons and inhibits excitotoxicity, which in turn may promote the development of oxidative stress in cells [132]. A number of other activities are also associated with the effect of zinc on the NMDA receptors, including the antidepressant activity [133].

Zinc deficiencies are very common in the population, and therefore, it is important to supplement this metal in the daily diet [134-136]. Among mushrooms, one of the best sources of zinc is $L$. edodes. In the study of Wang et al. [137], two fractions of zinc-containing polysaccharide were isolated from the cultures of $L$. edodes grown on media containing zinc sulfate. The fractions showed antiaging activity in vivo and antioxidant activity in in vitro tests (e.g., superoxide dismutase activity test, DPPH radical scavenging test). The content of zinc in the polysaccharides extracted from $L$. edodes was estimated as $2.95 \mathrm{mg} / \mathrm{g}$ [137].

Agaricus subrufescens is also characterized by a high content of zinc among mushrooms [138]. Using the atomic emission spectroscopy method, Kuziemska et al. [139] determined the content of zinc in several species of forest mushrooms. They found that I. badia was characterized by a very high content of zinc (on average $60.6 \mathrm{mg} / \mathrm{kg} \mathrm{d.w.),}$ while $P$. ostreatus and white $A$. bisporus contained a much lesser amount ( 25.7 and $29.8 \mathrm{mg} / \mathrm{kg} \mathrm{d}$.w., respectively) [139]. In addition, in a study performed in Spain [140], zinc content was determined in as many as 28 species of mushrooms growing in Lugo province. The highest content of this micronutrient was observed in Calvatia utriformis, L. deliciosus, and Agaricus macrosporus (265.8, 231, and $221.3 \mathrm{mg} / \mathrm{kg}$ d.w., respectively) using atomic absorption spectroscopy. The content of zinc determined in selected mushrooms from Pleurotus genus ranged from 4.38 to $9.41 \mathrm{mg} / 100 \mathrm{~g} \mathrm{d.w}$. for fruiting bodies, and from 7.18 to $14.96 \mathrm{mg} / 100 \mathrm{~g}$ d.w. for mycelia from in vitro cultures [70].

\section{Manganese}

Manganese can also exhibit antioxidant activity, due to the fact that, among others, it is a cofactor of manganese superoxide dismutase [141]. This form of the enzyme occurs primarily in the mitochondria, in contrast to zinc-copper dismutase which is mainly found in 
the cytosol [142]. Manganese superoxide dismutase is believed to be one of the most important enzymes that protect the body against the harmful effects of free radicals [143].

Turkekul et al. [144] analyzed the content of certain metals, including manganese, in 10 species of wild mushrooms growing in the Turkish province of Tokat. The highest content of manganese was found in Fomes fomentarius ( $64 \mathrm{mg} / \mathrm{kg} \mathrm{d} . \mathrm{w}$.), while a smaller amount was determined in Polyporus frondosus and Boletus appendiculatus (28 and $35 \mathrm{mg} / \mathrm{kg}$ d.w., respectively). In turn, a lower content of manganese was found in a study by Mallikarjuna et al. [145] which analyzed the elemental composition of four mushroom species. Among the species tested in the study, L. edodes $(10 \mathrm{mg} / \mathrm{kg} \mathrm{d.w.}$ ) and Pleutorus djamor (11.2 $\mathrm{mg} / \mathrm{kg} \mathrm{d}$.w.) proved to be the richest source of manganese. In the other two species of fungi (L. cladopus and Pleurotus florida), a lower content of this element was determined $(5.4$ and $6.2 \mathrm{mg} / \mathrm{kg} \mathrm{d} . \mathrm{w}$., respectively) [145].

\section{Magnesium}

Magnesium, which is also a macroelement, performs a number of important functions in living organisms. It is present in about 300 enzymes, participates in the active transport of calcium and potassium ions, and is required for proper nerve transmission and for maintaining the muscle tone and heart rate [146]. In addition, magnesium shows antioxidant properties. This element is involved in the biosynthesis of glutathione (GSH), an important endogenous antioxidant, where it takes part in the first stage of GSH formation, catalyzed by glutamate-cysteine ligase [147]. On the other hand, it has been demonstrated that magnesium deficiency is related to the development of oxidative stress. A very low level of magnesium in the body leads to the intensification of stress response, followed by which the activation of the sympathetic system, calcium cell overload (leading, among others, to excitotoxicity and neuronal damage), impairment of glutathione formation, and endothelial dysfunction occurs [148]. These processes in turn promote the intensification of lipid peroxidation and cell apoptosis. Moreover, magnesium deficiency increases the rate of oxidation of low-density lipoprotein, thus contributing to the destabilization of atherosclerotic plaques [149].

A large amount of magnesium is found in $M$. procera (approximately $1500 \mathrm{mg} / \mathrm{kg}$ d.w.) [150], B. edulis (approximately $800 \mathrm{mg} / \mathrm{kg}$ d.w.) [151], and Suillus granulatus (approximately $300 \mathrm{mg} / \mathrm{kg} \mathrm{d.w.)} \mathrm{[152].} \mathrm{It} \mathrm{is} \mathrm{worth} \mathrm{noting}$ that Dursun et al. [153] determined a very high content of magnesium in M. esculenta, exceeding $4000 \mathrm{mg} / \mathrm{kg}$ d.w.

\section{Copper}

Copper has both pro-oxidative and antioxidative properties [154, 155]. Its deficiency promotes the development of oxidative stress due to the inhibition of the antioxidant enzymes, such as copper- and zinc-dependent superoxide dismutase, or the most important copper-carrying protein in the body, ceruloplasmin [155]. Copper deficiency has been commonly reported in developed countries $[156,157]$, and hence, supplementation of this element seems to be the right approach to achieve health-promoting effects. There are reports on using the zeolites as substrate supplements in the process of the production of $G$. frondosa: Vunduk et al. [158, 159] utilized the modified natural zeolite Minazel Plus for this purpose. In case of copper level in G. frondosa, it was found that its level was significantly decreased in the fruiting bodies growing in the Minazel Plus-supplemented substrate (different outcomes were found for magnesium; the content of this element depended on the zeolite concentration) [159]. As indicated for the previously mentioned minerals, one of the sources of copper is fruiting mushrooms. A large amount of copper has been found in the fruiting bodies of $M$. procera (above $230 \mathrm{mg} / \mathrm{kg}$ d.w.), A. macrosporus (above $240 \mathrm{mg} / \mathrm{kg}$ d.w.), and C. utriformis (above $250 \mathrm{mg} / \mathrm{kg}$ d.w.) [140].

\section{Review of antioxidant components present in mushroom extracts obtained using artificial digestive juice}

The proper substrate composition, including biofortification with essential elements, and application of growing conditions enabling continuing supply of fruiting bodies of a market quality, and stabilized chemical composition, still remains a challenge. Many mushroom species are used for food preparation, moreover they are treated as functional food because they have health benefits beyond their nutritional value and therefore are used as natural medicines in many countries. Because of the rapid development of mushrooms farming, it is necessary to check at first the process of accumulation in in vitro conditions, and later used them in cultivations, and it is the routine schema in biotechnology $[70,125]$.

It is worth noting that not only the dry or fresh mushrooms but also the mushroom extracts are of interest in terms of the presence of antioxidant compounds. Thus far, a considerable number of works have focused on the kinetics and composition of the mushroom extracts obtained using artificial digestive juices [160-165]. Many of those studies were conducted at the Department of Inorganic and Analytical Chemistry, Jagiellonian University Medical College, using the Gastroel-2014 apparatus [166] which mimics the digestive system of humans. 
The release of indole compounds from three mushroom species (A. bisporus, I. badia, and C. cibarius) to the artificial stomach juice was investigated in a study by Muszyńska et al. [163]. The levels of the following four derivatives were assessed in the study: 5-hydroxy-L-tryptophan, L-tryptophan, serotonin, and 5-methyltryptamine. The highest concentration of 5-hydroxy-L-tryptophan $(109 \mathrm{mg} / 100 \mathrm{~g} \mathrm{~d} . \mathrm{w}$.) was found in the mycelium from in vitro culture of $C$. cibarius after $90 \mathrm{~min}$ of extraction, while the highest level of L-tryptophan $(15.8 \mathrm{mg} / 100 \mathrm{~g}$ d.w.) was found in the mycelium from in vitro culture of $I$. badia after $90 \mathrm{~min}$ of extraction [163]. The level of serotonin was very low, or the compound was totally absent in the samples, regardless of whether the fruiting bodies or the in vitro cultures were used for analysis. In the case of 5-methyltryptamine, the highest concentration $(35.5 \mathrm{mg} / 100 \mathrm{~g}$ d.w.) was detected in the mycelium from in vitro culture of $A$. bisporus, which was supplemented with zinc hydroaspartate, after $30 \mathrm{~min}$ of extraction [163].

The species A. bisporus was further examined by Muszyńska et al. [164] to verify whether the indole derivatives present in their in vitro cultures can be released into artificial digestive juice. The RP-HPLC (reverse phase high-performance liquid chromatography) analysis showed that L-tryptophan, melatonin, and serotonin, among others, were present in the lyophilized biomass obtained from the in vitro cultures of $A$. bisporus (either supplemented with zinc salts or not) that had been extracted into artificial gastric juice. The content of the released melatonin was the highest $(0.89 \mathrm{mg} / 100 \mathrm{~g}$ d.w. $)$ in the mycelium growing on Oddoux medium enriched with zinc sulfate $(174.47 \mathrm{mg} / \mathrm{L})$ after 90 min of extraction. The highest concentration of L-tryptophan $(4.68 \mathrm{mg} / 100 \mathrm{~g} \mathrm{~d}$.w.) was observed in the mycelium growing on Oddoux medium enriched with zinc hydroxyaspartate $(100 \mathrm{mg} / \mathrm{L})$ after $90 \mathrm{~min}$ of extraction; while in the case of serotonin, the peak level $(2.72 \mathrm{mg} / 100 \mathrm{~g} \mathrm{~d}$.w. $)$ was found in the mycelium growing on Oddoux medium supplemented with zinc sulfate $(174.47 \mathrm{mg} / \mathrm{L})$ after $60 \mathrm{~min}$ of extraction [164]. These findings show that $A$. bisporus may be a good source of antioxidant compounds.

In addition to the indole compounds, the release of zinc into the artificial digestive juices was analyzed in the work of Muszyńska et al. [165]. The fruiting bodies of I. badia, B. edulis, C. cibarius, Leccinum scabrum, P. ostreatus, and Suillus bovinus were assessed both before and after being thermal processing. Among the samples not subjected to high-temperature processing (boiling at $100{ }^{\circ} \mathrm{C}$ for $1 \mathrm{~h}$ in a water bath), the highest concentration of zinc was found for $L$. scabrum $(15.02 \mathrm{mg} / 100 \mathrm{~g}$ d.w.) in the artificial gastric juice after 120 min of extraction; whereas among the thermally processed samples, the highest concentration of this element was found for I. badia $(10.68 \mathrm{mg} / 100 \mathrm{~g} \mathrm{~d} . w$.$) in$ artificial intestine juice after $150 \mathrm{~min}$ of extraction.
Kała et al. [162] analyzed the level of zinc released to artificial digestive juice from the cultures of A. bisporus using the anodic stripping voltammetry method. The highest amount of the element ( $30.63 \mathrm{mg} / 100 \mathrm{~g} \mathrm{~d}$.w.) was determined in the cultures growing on Modified Oddoux Medium enriched with zinc hydroaspartate $(200 \mathrm{mg} / \mathrm{L})$ after $90 \mathrm{~min}$ of extraction into artificial gastric juice. A lower concentration of zinc was found in artificial saliva as well as in artificial intestinal juice, regardless of the type of medium used for culturing [162].

In another study, Kała et al. [161] determined the amount of indole and phenolic compounds in the extracts of the mushrooms obtained using artificial digestive juices (saliva, gastric juice, and intestinal juice). The following species were examined in the study: A. mellea, A. bisporus, A. polytricha, I. badia, B. edulis, C. cibarius, L. deliciosus, $L$. scabrum, S. bovinus, S. luteus, P. ostreatus, and Tricholoma equestre. A considerable number of antioxidant phenolic and indole compounds were assessed by the authors. One among them is melatonin, the highest content of which was found in the gastric juice extracts of T. equestre $(2.66 \mathrm{mg} / 100 \mathrm{~g}$ d.w.), S. luteus $(9.50 \mathrm{mg} / 100 \mathrm{~g}$ d.w.), and A. mellea $(22.9 \mathrm{mg} / 100 \mathrm{~g}$ d.w.) after $120 \mathrm{~min}$ of extraction [161]. Among the phenolic compounds, syringic acid was found to be at the highest concentrations in the gastric juice extract of the fruiting body of I. badia (19 mg/100 g d.w.), A. bisporus (11.1 mg/100 g d.w.), and B. edulis (10.2 mg/100 g d.w.) after $120 \mathrm{~min}$ of extraction. It was noted that the release of phenolic derivatives was generally better in the artificial gastric juice than in the artificial saliva and intestinal juice [161].

In addition, Kała et al. [160] determined the content of indole compounds and zinc released from the mycelial cultures of $I$. badia in the in vitro models. The authors found the highest amount of zinc $(176.01 \mathrm{mg} / 100 \mathrm{~g} \mathrm{~d}$.w $)$ in the mycelium growing on the zinc hydrogen aspartate-enriched medium. Among the indole derivatives, the level of melatonin in the extracts was too low to be assessed, but interestingly L-tryptophan was present at a level of $7.95 \mathrm{mg} / 100 \mathrm{~g}$ d.w. in the artificial gastric juice extract of the mycelium growing on Oddoux medium supplemented with zinc sulfate (VI), following $15 \mathrm{~min}$ of extraction [160].

It is worth mentioning that not only the composition of medium affects the bioavailability of the mushroom extracts. Important factors are also the ones being the features of the host's organism: health status of gastrointestinal tract, $\mathrm{pH}$ in gastrointestinal tract, rate of gastric emptying $[167,168]$. There are also dietary factors that may have an impact on the bioavailability of certain nutrients; in case of the bioavailability of polyphenols, Bohn lists inter alia dietary fiber (which may decrease available amount of polyphenols) dietary lipid (which increase the absorption of polyphenols); carbohydrates (which also, most probably, enhance the absorption of polyphenols) [169]. As for the nutrients 
originating from the mushrooms, there are a limited number of studies assessing the bioavailability in humans; one of them assessed the bioavailability of vitamin $\mathrm{D}_{2}$ (ergocalciferol) from $C$. tubaeformis in volunteers in Finland; it was found than ergocalciferol is better absorbed from lyophilized mushroom than from the fresh ones [170].

\section{Human trials in which mushroom extracts were evaluated for their antioxidant activity}

Numerous human clinical trials Phase I, II and III were conducted on various biologically active compounds isolated from medicinal mushrooms [171, 172]. Some of these compounds are used successfully in Asia to treat various cancers and other diseases [173]. In spite of the growing popularity of mushrooms, most of them are not well studied in respect of their clinical trials [174]. Mushroom-polysaccharides investigated in clinical trials include lentinan from L. edodes, schizophyllan from Schizophyllum commune, PSK and PSP from Trametes versicolor, grifron-D from $G$. frondosa, befungin from Inonotus obliquus, D-fraction from G. frondosa, G. lucidum polysaccharides fraction from $G$. lucidum [173, 175]. Extracts of G. lucidum due to the antioxidant characteristics were given orally for 30 days to 30 elderly people. Production of IL-2 and IFN was significantly increased after treatment with extracts of G. lucidum [175]. Cordyceps militaris is known as one of the most valuable medicinal mushrooms effective in the protection against oxidative stress. Administration of cordymin to rats significantly enhanced the mechanism against cerebral ischemia due to its antioxidant activity [176]. The effective anti-cancer properties of bioactive compounds isolated from medicinal mushrooms, e.g., lentinan, schizophyllan or maitake D-fraction as well as clinical benefits for patients during anti-cancer therapy were reviewed by several researchers [177]. However, more studies are needed with regard to human clinical trials to confirm the reports and demonstrate their relevance.

\section{Conclusions}

Mushrooms are a rich, but not very popular, source of antioxidants, yet. Due to their high content of antioxidant organic compounds and bioelements, many mushroom species can be considered as functional foods. Moreover, they are cholesterol free and contain organic substances such as tocopherols and carotenoids which help in protecting against the development of atherosclerotic lesions. Therefore, mushrooms can be treated as superfoods, which refer to unprocessed or low-processed foods having beneficial effects on human health and reduce the risk of a number of diseases. It is also worth noting that enrichment of medium and substrates used for mushroom cultivation enhances the level of the substances possessing antioxidant activity.

\section{Compliance with ethical standards}

Conflict of interest On behalf of all authors, the corresponding author states that there is no conflict of interest.

Ethical approval This article does not contain any studies with human participants or animal performed by any authors. No ethical approval was required.

Open Access This article is licensed under a Creative Commons Attribution 4.0 International License, which permits use, sharing, adaptation, distribution and reproduction in any medium or format, as long as you give appropriate credit to the original author(s) and the source, provide a link to the Creative Commons licence, and indicate if changes were made. The images or other third party material in this article are included in the article's Creative Commons licence, unless indicated otherwise in a credit line to the material. If material is not included in the article's Creative Commons licence and your intended use is not permitted by statutory regulation or exceeds the permitted use, you will need to obtain permission directly from the copyright holder. To view a copy of this licence, visit http://creativecommons.org/licenses/by/4.0/.

\section{References}

1. Dad S, Bisby RH, Clark IP, Parker AW (2006) Formation of singlet oxygen from solutions of vitamin E. Free Radic Res 40:333-338. https://doi.org/10.1080/10715760500491174

2. Nimse SB, Pal D (2015) Free radicals, natural antioxidants, and their reaction mechanisms. RSC Adv 5:27986-28006. https:// doi.org/10.1039/c4ra13315c

3. Bains VK, Bains R (2015) The antioxidant master glutathione and periodontal health. Dent Res J (Isfahan) 12:389-405. https ://doi.org/10.4103/1735-3327.166169

4. Sheng Y, Abreu IA, Cabelli DE et al (2014) Superoxide dismutases and superoxide reductases. Chem Rev 114:3854-3918. https://doi.org/10.1021/cr4005296

5. Alfonso-Prieto M, Biarnés X, Vidossich P, Rovira C (2009) The molecular mechanism of the catalase reaction. J Am Chem Soc 131:11751-11761. https://doi.org/10.1021/ja9018572

6. Mason RP, Casu M, Butler N et al (2013) Glutathione peroxidase activity is neuroprotective in models of Huntington's disease. Nat Genet 45:1249-1254. https://doi.org/10.1038/ng.2732

7. Chen L, Liu B (2017) Relationships between stress granules, oxidative stress, and neurodegenerative diseases. Oxid Med Cell Longev 2017:1809592. https://doi.org/10.1155/2017/1809592

8. Kattoor A, Pothineni N, Palagiri D, Mehta J (2017) Oxidative stress in atherosclerosis. Curr Atheroscler Rep 19:42. https://doi. org/10.1007/s11883-017-0678-6

9. Liguori I, Russo G, Curcio F et al (2018) Oxidative stress, aging, and diseases. Clin Interv Aging 13:757-772. https://doi. org/10.2147/CIA.S158513

10. Oguntibeju O (2019) Type 2 diabetes mellitus, oxidative stress and inflammation: examining the links. Int J Physiol Pathophysiol Pharmacol 11:45-63 
11. Cardwell G, Bornman JF, James AP, Black LJ (2018) A review of mushrooms as a potential source of dietary vitamin D. Nutrients 10:1498. https://doi.org/10.3390/nu10101498

12. Györfi J, Geösel A, Vetter J (2010) Mineral composition of different strains of edible medicinal mushroom Agaricus subrufescens Peck. J Med Food 13:1510-1514. https://doi.org/10.1089/ jmf.2009.0244

13. Orsine JVC, Novaes MRCG, Asquieri ER, Cañete R (2014) Determination of chemical antioxidants and phenolic compounds in the Brazilian Mushroom Agaricus sylvaticus. West Indian Med J 63:142-146. https://doi.org/10.7727/wimj.2011.216

14. Pourreza N (2013) Phenolic compounds as potential antioxidant. Jundishapur J Nat Pharm Prod 8:149-150. https://doi. org/10.1779/jjnpp-15380

15. Kim MY, Seguin P, Ahn JK et al (2008) Phenolic compound concentration and antioxidant activities of edible and medicinal mushrooms from Korea. J Agric Food Chem 56:7265-7270. https://doi.org/10.1021/jf8008553

16. Hatano T, Edamatsu R, Okuda T et al (1989) Effects of the interaction of tannins with co-existing substances. VI. Effects of tannins and related polyphenols on superoxide anion radical, and on 1, 1-diphenyl-2-picrylhydrazyl radical. Chem Pharm Bull 37:2016-2021. https://doi.org/10.1248/cpb.37.2016

17. Butkhup L, Samappito W, Jorjong S (2018) Evaluation of bioactivities and phenolic contents of wild edible mushrooms from northeastern Thailand. Food Sci Biotechnol 27:193-202. https ://doi.org/10.1007/s10068-017-0237-5

18. Yildiz O, Can Z, Laghari AQ et al (2015) Wild edible mushrooms as a natural source of phenolics and antioxidants. J Food Biochem 39:148-154. https://doi.org/10.1111/jfbc.12107

19. Muszyńska B, Sułkowska-Ziaja K, Ekiert H (2013a) Phenolic acids in selected edible basidiomycota species: Armillaria mellea, Boletus badius, Boletus edulis, Cantharellus cibarius, Lactarius deliciosus and Pleurotus ostreatus. Acta Sci Pol Hortorum Cultus 12:107-116

20. Gąsecka M, Mleczek M, Siwulski M, Niedzielski P (2016) Phenolic composition and antioxidant properties of Pleurotus ostreatus and Pleurotus eryngii enriched with selenium and zinc. Eur Food Res Technol 242:723-732. https://doi.org/10.1007/s0021 7-015-2580-1

21. Alispahić A, Šapčanin A, Salihović M et al (2015) Phenolic content and antioxidant activity of mushroom extracts from Bosnian market. Bull Chem Technol Bosnia Herzegovina 44:5-8

22. Gąsecka M, Magdziak Z, Siwulski M, Mleczek M (2018) Profile of phenolic and organic acids, antioxidant properties and ergosterol content in cultivated and wild growing species of Agaricus. Eur Food Res Technol 244:259-268. https://doi.org/10.1007/ s00217-017-2952-9

23. Froufe HJC, Abreu RMV, Ferreira ICFR (2009) A QCAR model for predicting antioxidant activity of wild mushrooms. SAR QSAR Environ Res 20:579-590. https://doi.org/10.1080/10629 360903408423

24. Karaman M, Jovin E, Malbaša R et al (2010) Medicinal and edible lignicolous fungi as natural sources of antioxidative and antibacterial agents. Phyther Res 24:1473-1481. https://doi. org/10.1002/ptr.2969

25. Cheung PCK (2010) The nutritional and health benefits of mushrooms. Nutr Bull 35:292-299. https://doi.org/10.111 1/j.1467-3010.2010.01859.x

26. Dubost NJ, Ou B, Beelman RB (2007) Quantification of polyphenols and ergothioneine in cultivated mushrooms and correlation to total antioxidant capacity. Food Chem 105:727-735. https:// doi.org/10.1016/j.foodchem.2007.01.030

27. Martinčič R, Mravljak J, Švajger U et al (2015) In silico discovery of novel potent antioxidants on the basis of pulvinic acid and coumarine derivatives and their experimental evaluation. PLoS ONE 10:e0140602. https://doi.org/10.1371/journal.pone.01406 02

28. Le Roux A, Josset E, Benzina S et al (2011) Evaluation of the radioprotective potential of the polyphenol norbadione A. Lett Drug Des Discov 9:48-53. https://doi.org/10.2174/1570180127 98192900

29. Korovitch A, Le Roux A, Barbault F et al (2013) A new series of $\mathrm{Cs}+, \mathrm{K}+$ and $\mathrm{Na}+$ chelators: synthesis, kinetics, thermodynamics and modeling. Inorg Chim Acta 394:45-57. https://doi. org/10.1016/j.ica.2012.08.009

30. Reczyński W, Muszyńska B, Opoka W et al (2013) Comparative study of metals accumulation in cultured in vitro mycelium and naturally grown fruiting bodies of Boletus badius and Cantharellus cibarius. Biol Trace Elem Res 153:355-362. https:// doi.org/10.1007/s12011-013-9670-3

31. Homer JA, Sperry J (2017) Mushroom-derived indole alkaloids. J Nat Prod 80:2178-2187. https://doi.org/10.1021/acs.jnatp rod.7b00390

32. Chanclud E, Morel JB (2016) Plant hormones: a fungal point of view. Mol Plant Pathol 17:1289-1297. https://doi.org/10.1111/ mpp. 12393

33. Muszyńska B, Maślanka A, Sułkowska-Ziaja K, Krzek J (2007) TLC-UV analysis of indole compounds and other nitrogencontaining bases in the fruiting bodies of Lactarius deterrimus. J Planar Chromatogr 20:57-60. https://doi.org/10.1556/ JPC.20.2007.1.9

34. Hardeland R, Pandi-Perumal SR (2005) Melatonin, a potent agent in antioxidative defense: actions as a natural food constituent, gastrointestinal factor, drug and prodrug. Nutr Metab 2:22. https://doi.org/10.1186/1743-7075-2-22

35. Reiter RJ, Mayo JC, Tan DX et al (2016) Melatonin as an antioxidant: under promises but over delivers. J Pineal Res 61:253-278. https://doi.org/10.1111/jpi.12360

36. Meng X, Li Y, Li S et al (2017) Dietary sources and bioactivities of melatonin. Nutrients 9:367. https://doi.org/10.3390/nu904 0367

37. Tan DX, Manchester LC, Esteban-Zubero E et al (2015) Melatonin as a potent and inducible endogenous antioxidant: synthesis and metabolism. Molecules 20:18886-18906. https://doi. org/10.3390/molecules201018886

38. Hardeland R (2016) Melatonin in plants-diversity of levels and multiplicity of functions. Front Plant Sci 7:198. https://doi. org/10.3389/fpls.2016.00198

39. Riga P, Medina S, García-Flores LA, Gil-Izquierdo Á (2014) Melatonin content of pepper and tomato fruits: effects of cultivar and solar radiation. Food Chem 156:347-352. https://doi. org/10.1016/j.foodchem.2014.01.117

40. Pytka K, Podkowa K, Rapacz A et al (2016) The role of serotonergic, adrenergic and dopaminergic receptors in antidepressant-like effect. Pharmacol Reports 68:263-274. https://doi. org/10.1016/j.pharep.2015.08.007

41. Azouzi S, Santuz H, Morandat S et al (2017) Antioxidant and membrane binding properties of serotonin protect lipids from oxidation. Biophys J 112:1863-1873. https://doi.org/10.1016/j. bpj.2017.03.037

42. Young SN (2007) How to increase serotonin in the human brain without drugs. J Psychiatry Neurosci 32:394-399

43. Muszyńska B, Komendacki P, Kała K et al (2014) L-tryptophan and its derivatives in edible mushrooms species. Med Int Rev 2:82-88

44. Muszyńska B, Piotrowska J, Krakowska A et al (2017) Study of physiologically active components in different parts of fruiting bodies of varieties of Agaricus bisporus (white mushroom). Eur 
Food Res Technol 243:2135-2145. https://doi.org/10.1007/s0021 7-017-2914-2

45. Muszyńska B, Sułkowska-Ziaja K, Ekiert H (2011a) Indole compounds in fruiting bodies of some edible Basidiomycota species. Food Chem 125:1306-1308. https://doi.org/10.1016/j.foodc hem.2010.10.056

46. Muszyńska B, Sułkowska-Ziaja K, Ekiert H (2013b) Analysis of indole compounds in methanolic extracts from the fruiting bodies of Cantharellus cibarius (the Chanterelle) and from the mycelium of this species cultured in vitro. J Food Sci Technol 50:1233-1237. https://doi.org/10.1007/s13197-013-1009-8

47. Muszyńska B, Sułkowska-Ziaja K, Ekiert H (2011b) Indole compounds in some culinary-medicinal higher Basidiomycetes from Poland. Int J Med Mushrooms 13:449-454. https://doi. org/10.1615/intjmedmushr.v13.i5.40

48. Rotola-Pukkila M, Yang B, Hopia A (2019) The effect of cooking on umami compounds in wild and cultivated mushrooms. Food Chem 278:56-66. https://doi.org/10.1016/j.foodc hem.2018.11.044

49. Zhu L, Wang S, Zhang Z et al (2019) Dissolution of bioactive components from dried fruiting bodies of the culinary-medicinal shiitake mushroom, entinus edodes (Agaricomycetes), during cleaning, soaking, and cooking. Int J Med Mushrooms 21:37-45. https://doi.org/10.1615/IntJMedMushrooms.2018029006

50. Muszyńska B, Sułkowska-Ziaja K (2012) Analysis of indole compounds in edible Basidiomycota species after thermal processing. Food Chem 132:455-459. https://doi.org/10.1016/j. foodchem.2011.11.021

51. Fiedor J, Burda K (2014) Potential role of carotenoids as antioxidants in human health and disease. Nutrients 6:466-488. https:// doi.org/10.3390/nu6020466

52. Im KH, Nguyen TK, Bin SD et al (2014) Appraisal of antioxidant and anti-inflammatory activities of various extracts from the fruiting bodies of Pleurotus florida. Molecules 19:3310-3326. https://doi.org/10.3390/molecules19033310

53. Jayaprakasha GK, Singh RP, Sakariah KK (2001) Antioxidant activity of grape seed (Vitis vinifera) extracts on peroxidation models in vitro. Food Chem 73:285-290. https://doi.org/10.1016/ S0308-8146(00)00298-3

54. Khachik F (2006) Distribution and metabolism of dietary carotenoids in humans as a criterion for development of nutritional supplements. Pure Appl Chem 78:1551-1557. https://doi. org/10.1351/pac200678081551

55. Thane C, Reddy S (1997) Processing of fruit and vegetables: effect on carotenoids. Nutr Food Sci 97:58-65. https://doi. org $/ 10.1108 / 00346659710161858$

56. Sharma SK, Gautam N (2015) Chemical, bioactive, and antioxidant potential of twenty wild culinary mushroom species. Biomed Res Int 2015:346508. https://doi.org/10.1155/2015/346508

57. Barros L, Baptista P, Ferreira ICFR (2007) Effect of Lactarius piperatus fruiting body maturity stage on antioxidant activity measured by several biochemical assays. Food Chem Toxicol 45:1731-1737. https://doi.org/10.1016/j.fct.2007.03.006

58. Ribeiro B, de Pinho PG, Andrade PB et al (2011) Do bioactive carotenoids contribute to the color of edible mushrooms? Open Chem Biomed Methods J 4:14-18. https://doi.org/10.2174/18750 38901104010014

59. Kozarski M, Klaus A, Vunduk J et al (2015) Nutraceutical properties of the methanolic extract of edible mushroom Cantharellus cibarius (Fries): Primary mechanisms. Food Funct 6:1875-1886. https://doi.org/10.1039/c5fo00312a

60. Kozarski M, Klaus A, Jakovljevic D et al (2015) Antioxidants of edible mushrooms. Molecules 20:19489-19525. https://doi. org/10.3390/molecules201019489
61. Gil-Ramírez A, Pavo-Caballero C, Baeza E et al (2016) Mushrooms do not contain flavonoids. J Funct Foods 25:1-13. https:// doi.org/10.1016/j.jff.2016.05.005

62. Shao Y, Guo H, Zhang J et al (2019) The genome of the medicinal macrofungus Sanghuang provides insights Into the synthesis of diverse secondary metabolites. Front Microbiol 10:3035. https ://doi.org/10.3389/fmicb.2019.03035

63. Tungmunnithum D, Thongboonyou A, Pholboon A, Yangsabai A (2018) Flavonoids and other phenolic compounds from medicinal plants for pharmaceutical and medical aspects: an overview. Medicines 5:93. https://doi.org/10.3390/medicines5030093

64. Pietta PG (2000) Flavonoids as antioxidants. J Nat Prod 63:10351042. https://doi.org/10.1021/np9904509

65. Xiao J (2017) Dietary flavonoid aglycones and their glycosides: which show better biological significance? Crit Rev Food Sci Nutr 57:1874-1905. https://doi.org/10.1080/10408 398.2015.1032400

66. Khoo HE, Azlan A, Tang ST, Lim SM (2017) Anthocyanidins and anthocyanins: colored pigments as food, pharmaceutical ingredients, and the potential health benefits. Food Nutr Res 61:1361779. https://doi.org/10.1080/16546628.2017.1361779

67. Kosanić M, Ranković B, Dašić M (2012) Mushrooms as possible antioxidant and antimicrobial agents. Iran J Pharm Res 11:1095-1102. https://doi.org/10.22037/ijpr.2012.1201

68. Barros L, Cruz T, Baptista P et al (2008) Wild and commercial mushrooms as source of nutrients and nutraceuticals. Food Chem Toxicol 46:2742-2747. https://doi.org/10.1016/j.fct.2008.04.030

69. Kała K, Kryczyk-Poprawa A, Rzewińska A, Muszyńska B (2020) Fruiting bodies of selected edible mushrooms as a potential source of lovastatin. Eur Food Res Technol 246:713-722. https ://doi.org/10.1007/s00217-020-03435-wEFRT-19-1328.R2

70. Krakowska A, Zięba P, Włodarczyk A et al (2020) Selected edible medicinal mushrooms from Pleurotus genus as an answer for human civilization diseases. Food Chem. https://doi. org/10.1016/j.foodchem.2020.127084

71. Chen SY, Ho KJ, Hsieh YJ et al (2012) Contents of lovastatin, $\gamma$-aminobutyric acid and ergothioneine in mushroom fruiting bodies and mycelia. Food Sci Technol 47:274-278. https://doi. org/10.1016/j.lwt.2012.01.019

72. Rizvi S, Raza ST, Ahmed F et al (2014) The role of vitamin E in human health and some diseases. Sultan Qaboos Univ Med J $14: 157-165$

73. Burton G, Joyce A, Ingold K (1983) Is vitamin E the only lipidsoluble, chain-breaking antioxidant in human blood plasma and erythrocyte membranes? Arch Biochem Biophys 221:281-290. https://doi.org/10.1016/0003-9861(83)90145-5

74. Vamanu E, Nita S (2013) Antioxidant capacity and the correlation with major phenolic compounds, anthocyanin, and tocopherol content in various extracts from the wild edible boletus edulis mushroom. Biomed Res Int 2013:313905. https://doi. org/10.1155/2013/313905

75. Heleno S, Barros L, Sousa M et al (2010) Tocopherols composition of Portuguese wild mushrooms with antioxidant capacity. Food Chem 119:1443-1450. https://doi.org/10.1016/j.foodc hem.2009.09.025

76. Toledo C, Barroetaveña C, Fernandes Â, et al (2016) Chemical and antioxidant properties of wild edible mushrooms from native nothofagus spp. forest, Argentina. Molecules 21:1201. https:// doi.org/https://doi.org/10.3390/molecules21091201

77. Bouzgarrou C, Amara K, Reis F et al (2018) Incorporation of tocopherol-rich extracts from mushroom mycelia into yogurt. Food Funct 9:3166-3172. https://doi.org/10.1039/c8fo00482j

78. Borel P, Caillaud D, Cano NJ (2015) Vitamin D bioavailability: state of the art. Crit Rev Food Sci Nutr 55:1193-1205. https:// doi.org/10.1080/10408398.2012.688897 
79. Jäpelt R, Jakobsen J (2013) Vitamin D in plants: a review of occurrence, analysis, and biosynthesis. Front Plant Sci 4:136. https://doi.org/10.3389/fpls.2013.00136

80. Schmid A, Walther B (2013) Natural vitamin D content in animal products. Adv Nutr 4:453-462. https://doi.org/10.3945/ an. 113.003780

81. Jäpelt RB, Didion T, Smedsgaard J, Jakobsen J (2011) Seasonal variation of provitamin $\mathrm{D}_{2}$ and vitamin $\mathrm{D}_{2}$ in perennial ryegrass (Lolium perenne L.). J Agric Food Chem 59:10907-10912. https ://doi.org/10.1021/jf202503c

82. Wiseman H (1993) Vitamin D is a membrane antioxidant Ability to inhibit iron-dependent lipid peroxidation in liposomes compared to cholesterol, ergosterol and tamoxifen and relevance to anticancer action. FEBS Lett 326:285-288. https://doi. org/10.1016/0014-5793(93)81809-E

83. Bennett L, Kersaitis C, Macaulay S et al (2013) Vitamin D2-enriched button mushroom (Agaricus bisporus) improves memory in both wild type and APPswe/PS1dE9 transgenic mice. PLoS ONE 8:e76362. https://doi.org/10.1371/journ al.pone. 0076362

84. Drori A, Rotnemer-Golinkin D, Avni S et al (2017) Attenuating the rate of total body fat accumulation and alleviating liver damage by oral administration of vitamin D-enriched edible mushrooms in a diet-induced obesity murine model is mediated by an anti-inflammatory paradigm shift. BMC Gastroenterol 17:130. https://doi.org/10.1186/s12876-017-0688-4

85. Huang SJ, Lin CP, Tsai SY (2015) Vitamin D2 content and antioxidant properties of fruit body and mycelia of edible mushrooms by UV-B irradiation. J Food Compos Anal 42:3845. https://doi.org/10.1016/j.jfca.2015.02.005

86. Taofiq O, Fernandes Â, Barros L et al (2017) UV-irradiated mushrooms as a source of vitamin D2: A review. Trends Food Sci, Technol

87. Phillips K, Ruggio D, Horst R et al (2011) Vitamin D and sterol composition of 10 types of mushrooms from retail suppliers in the United States. J Agric Food Chem 59:7841-7853. https:// doi.org/10.1021/jf104246z

88. Kalaras MD, Beelman RB, Elias RJ (2012) Effects of postharvest pulsed uv light treatment of white button mushrooms (Agaricus bisporus) on vitamin $\mathrm{D}_{2}$ content and quality attributes. J Agric Food Chem 60:220-225. https://doi.org/10.1021/ jf $203825 \mathrm{e}$

89. Guzen (2020) www.guzendevelopment.com/high-vitamin-dmushroom-powder*

90. Keegan RJH, Lu Z, Bogusz JM et al (2013) Photobiology of vitamin $\mathrm{D}$ in mushrooms and its bioavailability in humans. Dermatoendocrinol 5:165-176. https://doi.org/10.4161/derm.23321

91. Phillips K, Horst R, Koszewski N, Simon R (2012) Vitamin $D_{4}$ in mushrooms. PLoS ONE 7:e40702. https://doi.org/10.1371/ journal.pone.0040702

92. Sułkowska-Ziaja K, Hałaszuk P, Mastej M et al (2016) Mycosteroles-characteristics and biological importance. Med Int Rev 27:26-34

93. Padayatty S, Katz A, Wang Y et al (2003) Vitamin C as an antioxidant: evaluation of its role in disease orevention. J Am Coll Nutr 22:18-35. https://doi.org/10.1080/07315724.2003.10719 272

94. Pullar J, Carr A, Vissers M (2017) The roles of vitamin C in skin health. Nutrients 9:866. https://doi.org/10.3390/nu9080866

95. Smirnoff N (2018) Ascorbic acid metabolism and functions: A comparison of plants and mammals. Free Radic Biol Med 122:116-129. https://doi.org/10.1016/j.freeradbio med.2018.03.033

96. Nakalembe I, Kabasa J, Olila D (2015) Comparative nutrient composition of selected wild edible mushrooms from two agro-ecological zones, Uganda. Springerplus 4:433. https://doi. org/10.1186/s40064-015-1188-z

97. Nasiruddin M, Sultana M, Ali Haydar F et al (2018) Analysis of nutritional composition and antioxidant activity of oyster mushrooms grown in Bangladesh. Int J Food Sci Nutr 3:223-229

98. Bernaś E, Jaworska G, Lisiewska Z (2006) Edible mushrooms as a source of valuable nutritive constituents. Acta Sci Pol Technol Aliment 5:5-20

99. Higashi-Okai K, Nagino H, Yamada K, Okai Y (2006) Antioxidant and prooxidant activities of $\mathrm{B}$ group vitamins in lipid peroxidation. J UOEH 28:359-368. https://doi.org/10.7888/juoeh .28 .359

100. Jaworska G, Pogoń K, Skrzypczak A, Bernaś E (2015) Composition and antioxidant properties of wild mushrooms Boletus edulis and Xerocomus badius prepared for consumption. $\mathbf{J}$ Food Sci Technol 52:7944-7953. https://doi.org/10.1007/s1319 7-015-1933-x

101. Jaworska G, Pogoń K, Bernaś E, Duda-Chodak A (2015) Nutraceuticals and antioxidant activity of prepared for consumption commercial mushrooms Agaricus bisporus and Pleurotus ostreatus. J Food Qual 38:111-122. https://doi.org/10.1111/jfq.12132

102. Çağlarirmak $\mathrm{N}$ (2007) The nutrients of exotic mushrooms (Lentinula edodes and Pleurotus species) and an estimated approach to the volatile compounds. Food Chem 105:1188-1194. https:// doi.org/10.1016/j.foodchem.2007.02.021

103. Paul B, Snyder S (2010) The unusual amino acid L-ergothioneine is a physiologic cytoprotectant. Cell Death Differ 17:1134-1140. https://doi.org/10.1038/cdd.2009.163

104. Cheah I, Halliwell B (2012) Ergothioneine; antioxidant potential, physiological function and role in disease. Biochim Biophys Acta 1822:784-793. https://doi.org/10.1016/j.bbadis.2011.09.017

105. Frigeni M, Iacobazzi F, Yin X, Longo N (2016) Wide tolerance to amino acids substitutions in the OCTN1 ergothioneine transporter. Biochim Biophys Acta 1860:1334-1342. https://doi. org/10.1016/j.bbagen.2016.03.021

106. Kalaras MD, Richie JP, Calcagnotto A, Beelman RB (2017) Mushrooms: A rich source of the antioxidants ergothioneine and glutathione. Food Chem 233:429-433. https://doi.org/10.1016/j. foodchem.2017.04.109

107. Song T, Yang N, Chen C, Thi T (2017) Protective effects and possible mechanisms of ergothioneine and hispidin against methylglyoxal-induced injuries in rat pheochromocytoma cells. Oxid Med Cell Longev 2017:4824371. https://doi. org/10.1155/2017/4824371

108. Lee WY, Park E-J, Ahn JK, Ka K-H (2009) Ergothioneine contents in fruiting bodies and their enhancement in mycelial cultures by the addition of methionine. Mycobiology 37:43-47. https://doi.org/10.4489/myco.2009.37.1.043

109. Muszyńska B, Sułkowska-Ziaja K, Ekiert H (2010) Główne grupy związków i pierwiastki z aktywnością biologiczną w wybranych gatunkach grzybów z taksonu Basidiomycota. Farm Pol 66:804-814

110. Muszyńska B, Kała K, Rojowski J et al (2017) Composition and biological properties of Agaricus bisporus fruiting bodies-a review. Polish J Food Nutr Sci 67:173-182. https://doi. org/10.1515/pjfns-2016-0032

111. Khanna JM, Malone MH, Euler KL, Brady LR (1965) Atromentin. Anticoagulant from Hydnellum diabolus. J Pharm Sci 54:1016-1020. https://doi.org/10.1002/jps.2600540714

112. Sullivan G, Guess WL (1969) Atromentin: a smooth muscle stimulant in Clitocybe subilludens. Lloydia 32:72-75

113. Zheng CJ, Sohn MJ, Kim WG (2006) Atromentin and leucomelone, the first inhibitors specific to enoyl-ACP reductase (FabK) of Streptococcus pneumoniae. J Antibiot (Tokyo) 59:808-812. https://doi.org/10.1038/ja.2006.108 
114. Burton J, Cain B (1959) Antileukæmic activity of polyporic acid. Nature 184:1326-1327. https://doi.org/10.1038/1841326a0

115. Athanasakis G, Aligiannis N, Gonou-Zagou Z et al (2013) Antioxidant properties of the wild edible mushroom Lactarius salmonicolor. J Med Food 16:760-764. https://doi.org/10.1089/ jmf.2012.0297

116. Sizova NV (2012) Composition and antioxidant activity of essential oils containing azulene derivatives. Pharm Chem J 46:369371. https://doi.org/10.1007/s11094-012-0800-6

117. Harmon AD, Weisgraber KH, Weiss U (1980) Preformed azulene pigments of Lactarius indigo (Schw.) Fries (Russulaceae, Basidiomycetes). Experientia 36:54-56. https://doi.org/10.1007/BF020 03967

118. Feussi Tala M, Qin J, Ndongo J, Laatsch H (2017) New azulenetype sesquiterpenoids from the fruiting bodies of Lactarius deliciosus. Nat Prod Bioprospect 7:269-273. https://doi.org/10.1007/ s13659-017-0130-1

119. Tinggi $U$ (2008) Selenium: its role as antioxidant in human health. Environ Health Prev Med 13:102-108. https://doi. org/10.1007/s12199-007-0019-4

120. Górski K, Kondracki S, Saba L (2018) Selenium concentration in soil, and in the feed and hair coat of Polish Holstein-Friesian cows administered a mineral mixture. Indian J Anim Sci $88: 1207-1210$

121. Wasowicz W, Gromadzinska J, Rydzynski K, Tomczak J (2003) Selenium status of low-selenium area residents: Polish experience. Toxicol Lett 137:95-101. https://doi.org/10.1016/S0378 -4274(02)00383-1

122. Orian L, Mauri P, Roveri A et al (2015) Selenocysteine oxidation in glutathione peroxidase catalysis: An MS-supported quantum mechanics study. Free Radic Biol Med 87:1-14. https ://doi.org/10.1016/j.freeradbiomed.2015.06.011

123. Guo F, Monsefi N, Moritz A, Beiras-Fernandez A (2015) Selenium and cardiovascular surgery: an overview. Curr Drug Saf 7:321-327. https://doi.org/10.2174/1574886311207040321

124. Mirończuk-Chodakowska I, Socha K, Zujko ME et al (2019) Copper, manganese, selenium and zinc in wild-growing edible mushrooms from the eastern territory of "Green Lungs of Poland": nutritional and toxicological implications. Int $\mathbf{J}$ Environ Res Public Health 16:3614. https://doi.org/10.3390/ ijerph16193614

125. Zięba P, Kała K, Włodarczyk A et al (2020) Selenium and Zinc Biofortification of Pleurotus eryngii mycelium and fruiting bodies as a tool for controlling their biological activity. Molecules 25:889. https://doi.org/10.3390/molecules250408 89

126. Zhou F, Yang W, Wang M et al (2018) Effects of selenium application on Se content and speciation in Lentinula edodes. Food Chem 265:182-188. https://doi.org/10.1016/j.foodc hem.2018.05.087

127. Lee SR (2018) Critical role of zinc as either an antioxidant or a prooxidant in cellular systems. Oxid Med Cell Longev 2018:9156285. https://doi.org/10.1155/2018/9156285

128. Prasad AS (2014) Zinc is an antioxidant and anti-inflammatory agent: Its role in human health. Front Nutr 1:14. https://doi. org/10.3389/fnut.2014.00014

129. Andreini C, Bertini I (2012) A bioinformatics view of zinc enzymes. J Inorg Biochem 111:150-156. https://doi. org/10.1016/j.jinorgbio.2011.11.020

130. Virgili F, Canali R, Figus E et al (1999) Intestinal damage induced by zinc deficiency is associated with enhanced CuZn superoxide dismutase activity in rats effect of dexamethasone or thyroxine treatment. Free Radic Biol Med 26:1194-1201. https://doi.org/10.1016/S0891-5849(98)00307-4
131. Oteiza PI (2012) Zinc and the modulation of redox homeostasis. Free Radic Biol Med 53:1748-1759. https://doi. org/10.1016/j.freeradbiomed.2012.08.568

132. Marreiro D, Cruz K, Morais J et al (2017) Zinc and oxidative stress: Current mechanisms. Antioxidants 6:24. https://doi. org/10.3390/antiox6020024

133. Młyniec K (2015) Zinc in the glutamatergic theory of depression. Curr Neuropharmacol 13:505-513. https://doi. org/10.2174/1570159x13666150115220617

134. Mocchegiani E, Romeo J, Malavolta M et al (2013) Zinc: Dietary intake and impact of supplementation on immune function in elderly. Age (Omaha) 35:839-860. https://doi.org/10.1007/ s11357-011-9377-3

135. Prasad AS (2013) Discovery of human zinc deficiency: Its impact on human health and disease. Adv Nutr 4:176-190. https://doi.org/10.3945/an.112.003210

136. Terrin G, Canani RB, Di Chiara M et al (2015) Zinc in early life: A key element in the fetus and preterm neonate. Nutrients 7:10427-10446. https://doi.org/10.3390/nu7125542

137. Wang L, Wang C, Gao X et al (2015) Purification, characterization and anti-aging capacity of mycelia zinc polysaccharide by Lentinus edodes SD-08. BMC Complement Altern Med 15:111. https://doi.org/10.1186/s12906-015-0630-7

138. Wisitrassameewong K, Karunarathna SC, Thongklang $\mathrm{N}$ et al (2012) Agaricus subrufescens: a review. Saudi J Biol Sci 19:131146. https://doi.org/10.1016/j.sjbs.2012.01.003

139. Kuziemska B, Wysokiński A, Jaremko D, et al (2018) Zawartość wybranych metali ciężkich w grzybach jadalnych. Inżynieria Ekol 19:66-70. https://doi.org/https://doi.org/10.12912/23920 $629 / 81652$

140. Alonso J, García MA, Pérez-López M, Melgar MJ (2003) The concentrations and bioconcentration factors of copper and zinc in edible mushrooms. Arch Environ Contam Toxicol 44:180-188. https://doi.org/10.1007/s00244-002-2051-0

141. Aguirre JD, Culotta VC (2012) Battles with iron: manganese in oxidative stress protection. J Biol Chem 287:13541-13548. https ://doi.org/10.1074/jbc.R111.312181

142. Skrzycki M, Czeczot A (2005) Rola dysmutazy ponadtlenkowej w powstawaniu nowotworów. Postępy Nauk Med 4:7-15

143. Sarsour EH, Kalen AL, Goswami PC (2013) Manganese superoxide dismutase regulates a redox cycle within the cell cycle. Antioxid Redox Signal 20:1618-1627. https://doi.org/10.1089/ ars. 2013.5303

144. Turkekul I, Elmastas M, Tüzen M (2004) Determination of iron, copper, manganese, zinc, lead, and cadmium in mushroom samples from Tokat, Turkey. Food Chem 84:389-392. https://doi. org/10.1016/S0308-8146(03)00245-0

145. Mallikarjuna SE, Ranjini A, Haware DJ et al (2013) Mineral composition of four edible mushrooms. J Chem 2013:1-5. https ://doi.org/10.1155/2013/805284

146. Gröber U, Schmidt J, Kisters K (2015) Magnesium in prevention and therapy. Nutrients 7:8199-8226. https://doi.org/10.3390/ nu7095388

147. Lu SC (2009) Regulation of glutathione synthesis. Mol Aspects Med 30:42-59. https://doi.org/10.1016/j.mam.2008.05.005

148. Zheltova AA, Kharitonova MV, Iezhitsa IN, Spasov AA (2016) Magnesium deficiency and oxidative stress: an update. Biomed 6:20. https://doi.org/10.7603/s40681-016-0020-6

149. Wegner M, Araszkiewicz A, Zozulińska-Ziółkiewicz D et al (2010) The relationship between concentrations of magnesium and oxidized low density lipoprotein and the activity of platelet activating factor acetylhydrolase in the serum of patients with type 1 diabetes. Magnes Res 23:97-104. https://doi.org/10.1684/ mrh.2010.0207 
150. Kułdo E, Jarzyńska G, Gucia M, Falandysz J (2014) Mineral constituents of edible parasol mushroom Macrolepiota procera (Scop. ex Fr.) Sing and soils beneath its fruiting bodies collected from a rural forest area. Chem Pap 68:484-492. https:// doi.org/10.2478/s11696-013-0477-7

151. Zhang D, Frankowska A, Jarzyńska G et al (2010) Metals of king bolete (Boletus edulis) bull.: Fr. collected at the same site over two years. African J Agric Res 5:3050-3055

152. Arce S, Cerutti S, Olsina R et al (2008) Trace element profile of a wild edible mushroom (Suillus granulatus). J AOAC Int 91:853-857. https://doi.org/10.1093/jaoac/91.4.853

153. Dursun N, Özcan MM, Kaşik G, Öztürk C (2006) Mineral contents of 34 species of edible mushrooms growing wild in Turkey. J Sci Food Agric 86:1087-1094. https://doi.org/10.1002/ jsfa. 2462

154. Gaetke LM, Chow CK (2003) Copper toxicity, oxidative stress, and antioxidant nutrients. Toxicology 189:147-163. https://doi. org/10.1016/S0300-483X(03)00159-8

155. Kays SE, Fischer JG (1992) Is copper an antioxidant nutrient? Crit Rev Food Sci Nutr 32:1-31. https://doi.org/10.1080/10408 399209527578

156. Allen KG, Klevay LM (1994) Copper: an antioxidant nutrient for cardiovascular health. Curr Opin Lipidol 5:22-28. https:// doi.org/10.1097/00041433-199402000-00005

157. Wazir SM, Ghobrial I (2017) Copper deficiency, a new triad: anemia, leucopenia, and myeloneuropathy. J Community Hosp Intern Med Perspect 7:265-268. https://doi.org/10.1080/20009 666.2017.1351289

158. Vunduk J, Klaus A, Kozarski M et al (2016) Addition of zeolites to improve the functional characteristics of the hen of the wood or maitake medicinal mushroom, Grifola frondosa (Agaricomycetes). Int J Med Mushrooms 18:781-792. https://doi. org/10.1615/IntJMedMushrooms.v18.i9.30

159. Vunduk J, Klaus A, Kozarski M et al (2014) Zeolites as possible biofortifiers in Maitake cultivation. Arch Biol Sci 66:123-129. https://doi.org/10.2298/ABS1401123V

160. Kała K, Krakowska A, Gdula-Argasińska J et al (2019) Assessing the bioavailability of zinc and indole compounds from mycelial cultures of the bay mushroom Imleria badia (Agaricomycetes) using in vitro models. Int J Med Mushrooms 21:343-352. https ://doi.org/10.1615/IntJMedMushrooms.2019030328

161. Kała K, Krakowska A, Sułkowska-Ziaja K et al (2017) Kinetics of extracted bioactive components from mushrooms in artificial digestive juices. Int J Food Prop 20:1796-1817. https://doi. org/10.1080/10942912.2016.1219742

162. Kała K, Muszyńska B, Zając M et al (2016) Determination of zinc(II) ions released into artificial digestive juices from culinary-medicinal button mushroom, Agaricus bisporus (Agaricomycetidae), biomass of in vitro cultures using an anodic stripping voltammetry method. Int J Med Mushrooms 18:155-164. https ://doi.org/10.1615/IntJMedMushrooms.v18.i2.60

163. Muszyńska B, Kała K, Sułkowska-Ziaja K et al (2015) Determination of indole compounds released from selected edible mushrooms and their biomass to artificial stomach juice. LWT - Food Sci Technol 62:27-31. https://doi.org/10.1016/j.lwt.2015.01.037
164. Muszyńska B, Kała K, Sułkowska-Ziaja K et al (2016) Agaricus bisporus and its in vitro culture as a source of indole compounds released into artificial digestive juices. Food Chem 199:509-515. https://doi.org/10.1016/j.foodchem.2015.12.041

165. Muszyńska B, Zajac M, Kała K et al (2016) Thermal processing can affect zinc availability in some edible mushrooms. Food Sci Technol 199:509-515. https://doi.org/10.1016/j.lwt.2016.01.078

166. Opoka W, Muszyńska B, Rojowski J, Rumian J (2016) Gastroel-2014. Poland Patent Application P 417238

167. Nimmo WS (1976) Drugs, diseases and altered gastric emptying. Clin Pharmacokinet 1:189-203. https://doi.org/10.2165/00003 088-197601030-00002

168. Abuhelwa AY, Williams DB, Upton RN, Foster DJR (2017) Food, gastrointestinal $\mathrm{pH}$, and models of oral drug absorption. Eur J Pharm Biopharm 112:234-248. https://doi.org/10.1016/j. ejpb.2016.11.034

169. Bohn T (2014) Dietary factors affecting polyphenol bioavailability. Nutr Rev 72:49-52. https://doi.org/10.1111/nure.12114

170. Outila TA, Mattila PH, Piironen VI, Lamberg-Allardt CJE (1999) Bioavailability of vitamin D from wild edible mushrooms (Cantharellus tubaeformis) as measured with a human bioassay. Am J Clin Nutr 69:95-98. https://doi.org/10.1093/ajcn/69.1.95

171. Wasser S (2017) Medicinal mushrooms in human clinical studies. Part I. anticancer, oncoimmunological, and immunomodulatory activities: a review. Int J Med Mushrooms 19:279-317. https:// doi.org/10.1615/intjmedmushrooms.v19.i4.10

172. Sharma D, Singh V, Singh N (2018) A review on phytochemistry and pharmacology of medicinal as well as poisonous mushrooms. Mini Rev Med Chem 18:1095-1109. https://doi. org/10.2174/1389557517666170927144119

173. Wasser S (2011) Current findings, future trends, and unsolved problems in studies of medicinal mushrooms. Appl Microbiol Biotechnol 89:1323-1332. https://doi.org/10.1007/s0025 3-010-3067-4

174. Money NP (2016) Are mushrooms medicinal? Fungal Biol 120:449-453. https://doi.org/10.1016/j.funbio.2016.01.006

175. Smith JE, Rowan NJ, Sullivan R (2002) Medicinal mushrooms: their therapeutic properties and current medical usage with special emphasis on cancer treatments. Cancer Research UK, London

176. Roupas P, Keogh J, Noakes M et al (2012) The role of edible mushrooms in health: evaluation of the evidence. J Funct Foods 4:687-709. https://doi.org/10.1016/j.jff.2012.05.003

177. De Silva DD, Rapior S, Fons F et al (2012) Medicinal mushrooms in supportive cancer therapies: an approach to anti-cancer effects and putative mechanisms of action. Fungal Divers 55:135. https://doi.org/10.1007/s13225-012-0151-3

Publisher's Note Springer Nature remains neutral with regard to jurisdictional claims in published maps and institutional affiliations. 